\title{
On the Phosphorus Evaporation from Liquid Silicon by Knudsen Effusion Mass Spectrometry
}

\author{
ARMAN HOSEINPUR, DMITRY SERGEEV, MICHAEL MÜLLER, \\ and JAFAR SAFARIAN
}

Silicon refining for solar applications is intensively on demand, and removal of phosphorus from $\mathrm{Si}$ is one of the most challenging steps. Evaporation of $\mathrm{P}$ from liquid $\mathrm{Si}$ in a vacuum refining process is the most efficient method for $\mathrm{P}$ removal from $\mathrm{Si}$, and this research deals with the insight mechanisms of $\mathrm{P}$ evaporation from liquid $\mathrm{Si}$. In this research, the gaseous species evaporating from the dilute liquid solutions of phosphorus in silicon were studied experimentally, and it was shown that phosphorus evaporates in the form of $\mathrm{P}, \mathrm{P}_{2}, \mathrm{P}_{4}, \mathrm{P}_{3}$, $\mathrm{SiP}, \mathrm{Si}_{2} \mathrm{P}, \mathrm{Si}_{3} \mathrm{P}$, and $\mathrm{SiP}_{2}$ at elevated temperatures. Except $\mathrm{P}$ and $\mathrm{P}_{2}$, the other molecules were detected experimentally for the first time, and $\mathrm{Si}_{3} \mathrm{P}$ was detected as a new compound in the gas phase. Knudsen effusion mass spectrometry technique was applied to characterize the evaporation of phosphorus from liquid Si samples containing 100, 1250, and $3000 \mathrm{ppmw}$ phosphorus. The evaporation of phosphorus from liquid $\mathrm{Si}$ was studied by isothermal and polythermal experiments, up to $1840^{\circ} \mathrm{C}$. The vapor pressures of various P-containing molecules $\left(\mathrm{P}, \mathrm{P}_{2}, \mathrm{P}_{4}, \mathrm{SiP}, \mathrm{Si}_{2} \mathrm{P}\right)$ at $1442{ }^{\circ} \mathrm{C}$ were measured as a function of phosphorus fraction in liquid silicon. Results indicated that a major part of the phosphorus evaporates in the form of silicon phosphides and $\mathrm{P}_{4}$, especially when the sample temperature exceeds $1750{ }^{\circ} \mathrm{C}$. When initial phosphorus was $100 \mathrm{ppmw}$, about $71 \mathrm{pct}$ of phosphorus evaporation was by means of silicon phosphides and $\mathrm{P}_{4}$. The mechanisms of phosphorus evaporation from liquid $\mathrm{Si}$ are proposed, which depend on the melt composition and temperature. It occurs through phosphorus species evaporation independently or via the decomposition of transient silicon phosphides at the surface or through the direct evaporation of silicon phosphides at the melt surface.

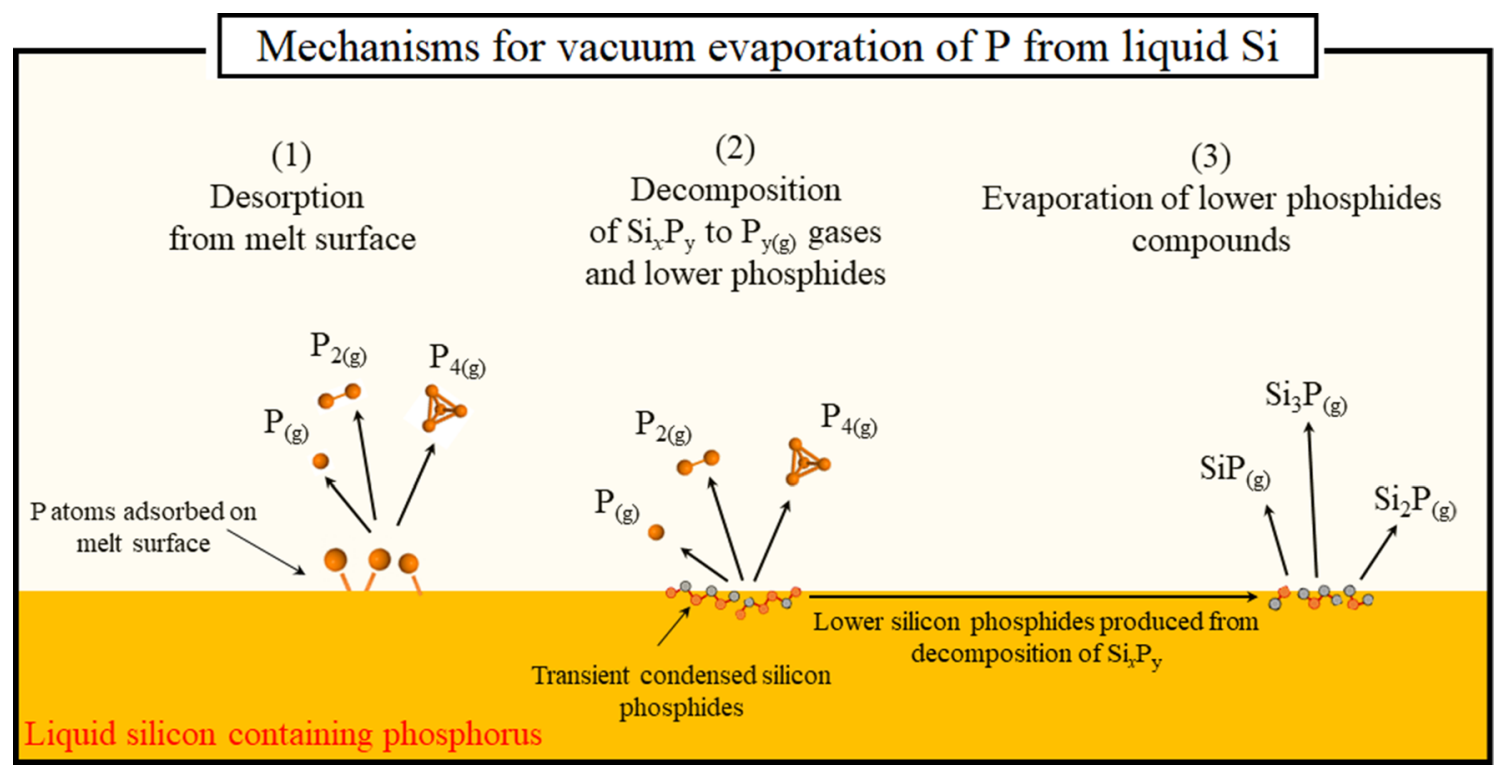

ARMAN HOSEINPUR and JAFAR SAFARIAN are with the Department of Material Science and Engineering, Norwegian University of Science and Technology (NTNU), 7034 Trondheim, Norway. Contact e-mail: arman.h.kermani@ntnu.no DMITRY SERGEEV and MICHAEL MÜLLER are with the Institute of Energy and Climate Research-IEK 2, Forschungszentrum Jülich GmbH, Wilhelm-Johnen-Straße, 52428 Jülich, Germany.

Manuscript submitted February 2, 2021; accepted January 11, 2022.

Article published online February 11, 2022. 


\section{INTRODUCTION}

SILICON refining for production of Si solar cells is a hot topic attracting many researchers in recent years. The solar-grade silicon (SoG-Si) requires a minimum purity of 99.9999 pct $(6 \mathrm{~N})^{[1-5]}$; hence, dedicated refining methods are required for removing these impurities. One of the most important impurities that is difficult to remove from metallurgical $\mathrm{Si}$ is phosphorus (with tens of ppmw). Therefore, dedicated refining techniques are required for removal of $\mathrm{P}$ from $\mathrm{Si}^{[6-14]}$ as it is not effectively removed via directional solidification of ingot casting. On the other hand, phosphorus is also one of the most detrimental impurities that can affect the efficiency of silicon solar cells. ${ }^{[15]}$ Currently, $>90$ pct of the photovoltaic (PV) solar modules are produced from silicon, ${ }^{[15-17]}$ and production of PV modules is increasing, as it expanded seven-fold from 2010 to 2019. ${ }^{[18]}$ Therefore, developing new processes with proper control of phosphorus in SoG-Si is important. ${ }^{[19]}$ Nowadays, up to 0.2 ppmw of phosphorus in $\mathrm{Si}$ is accepted as the limit for SoG-Si production, which could be reduced in the future if higher efficiencies are required. ${ }^{[20]}$ Many research works have been carried out in the recent years on removal of $\mathrm{P}$ from $\mathrm{Si}^{[8,9,21-28]}$ and many of them were focused on vacuum refining. ${ }^{[1,4,5,12,29-37]}$ According to literature and our previous works, vacuum refining of $\mathrm{Si}$ is one of the most efficient and clean methods for the complete removal of phosphorus from Si. ${ }^{[38-40]}$ Vacuum refining of $\mathrm{Si}$ has been investigated over the past 30 years and recently pilot tested/industrialized by Ferroglobe ${ }^{[1,41]}$ The vacuum evaporation from free surfaces is called Langmuir evaporation, ${ }^{[6,12,42-45]}$ and hence all the research carried out for vacuum refining of Si lies in this category. Vacuum evaporation can also be studied by Knudsen technique ${ }^{[46]}$ where the liquid evaporates in a tiny enclosure (cell) with an orifice on top, providing a molecular beam effusing out of the cell. This beam can be characterized by spectrometers to track the evaporated molecules. Such a combination is called Knudsen effusion mass spectrometry (KEMS) ${ }^{[47-51]}$ which provides valuable data about high temperature gases and vapor pressure measurements of metals and alloys. ${ }^{[49,52-60]}$

Metallurgy of the $\mathrm{Si}-\mathrm{P}$ system is difficult to study because of high vapor pressure of $\mathrm{P}$ at high temperatures, requirement of dedicated instruments, and uncertainties about the gaseous species and compositions. The known gaseous components in the $\mathrm{Si}-\mathrm{P}$ system and at elevated temperatures are $\mathrm{P}$ and $\mathrm{P}_{2}$; however, the presence of $\mathrm{SiP}, \mathrm{Si}_{2} \mathrm{P}$, and $\mathrm{Si}_{2} \mathrm{P}_{2}$ has been claimed from theoretical models. ${ }^{\left[{ }^{1} 1\right]}$ Both thermodynamics of the liquid $\mathrm{Si}-\mathrm{P}$ system and mass transport of the species between liquid and gas are reported in the literature. ${ }^{[62-65]}$ The thermochemistry of dilute solutions of phosphorus in $\mathrm{Si}$ melt has already been investigated experimentally by Miki et al. ${ }^{[62]}$ and Zaitsev et al., ${ }^{[63]}$ and it is theoretically modeled by Liang and Fetzer in Reference 61. Table I gives a summary of these studies. Miki et al. ${ }^{[62]}$ investigated the established equilibrium of Si melt with introduced phosphorus gas in graphite and alumina crucibles and obtained the Gibbs free energy change for the equilibrium between the dissolved phosphorus in liquid $\mathrm{Si}(\underline{\mathrm{P}})$ and $\mathrm{P}_{2(\mathrm{~g})}$. Zaitsev et al. ${ }^{[63]}$ applied the Knudsen effusion mass spectrometry (KEMS) method to investigate the vapor pressure of phosphorus species effusing from $\mathrm{Si}-\mathrm{P}$ samples with various concentrations of phosphorus in liquid $\mathrm{Si}$ and obtained the Gibbs free energy for the evaporation of $\mathrm{P}_{2(\mathrm{~g})}$ from $\mathrm{Si}$ melt. The previous studies on vacuum refining of silicon ${ }^{[40,66]}$ were focused on the mass transport of impurities. It has been shown that chemical evaporation at the melt surface and gas phase mass transport could control the kinetics of the vacuum induction refining of silicon. Generally, the desorption of phosphorus atoms from the melt surface is assumed as the main mechanism for phosphorus evaporation from silicon. In all previous works, ${ }^{[3,4,40,62,66-70]}$ the monoatomic and diatomic desorption of phosphorus at the melt surface has been assumed.

In our previous work ${ }^{[6]}$ on vacuum refining of silicon at ultra-high temperatures (UHT, by definition $T_{\mathrm{UHT}} \geq$ $1.25 T_{m, \mathrm{Si}}$ ), we showed the apparent mass transfer of phosphorus increases significantly when the temperature of the refining approaches UHTs. ${ }^{[6]}$ In the same work, ${ }^{[6]}$ we proposed the hypothesis of decomposition of transient silicon phosphides on the melt surface to explain the acceleration of mass transfer of phosphorus to the gas phase. In this research, we applied KEMS to characterize the vacuum evaporation of phosphorus from liquid $\mathrm{Si}$ and will compare the obtained results with the results from the Si refining experiments. The results of this article will provide insightful knowledge about the $\mathrm{Si}-\mathrm{P}$ system and hence will contribute to the field of Si refining.

\section{EXPERIMENTAL PROCEDURE}

\section{A. Si-P Sample Preparation}

For this study, a Si-P alloy with $3715 \pm 200$ ppmw of phosphorus was initially made by adding red phosphorus to $400 \mathrm{~g}$ of $\mathrm{Si}$ melt at $1500{ }^{\circ} \mathrm{C}$. The alloying process was carried out in a graphite crucible (properties mentioned in Reference 7). For this purpose, polysilicon 


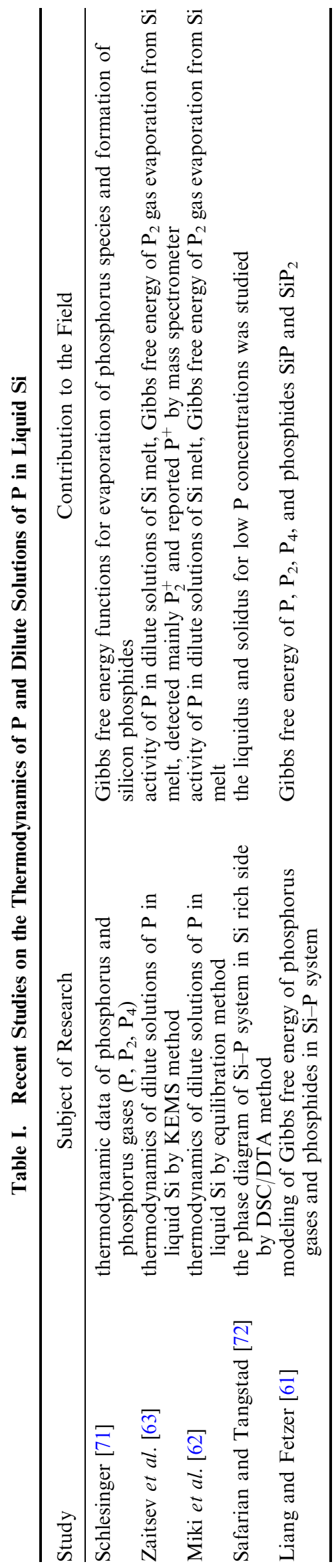

(FBR ${ }^{\circledR}$ purity $8 \mathrm{~N}$ ) was charged into the graphite crucible. Then, it was melted in a vacuum induction furnace under $\operatorname{Ar}(6 \mathrm{~N})$ atmosphere; subsequently, red phosphorus was added to the silicon melt and the alloy was then cast in a water-cooled copper mold. This Si-P alloy was then characterized by ICP-MS. More details about the silicon high phosphorus alloy production can be found in Reference 39. To study the gas phase over various melt phosphorus concentrations, we mixed and re-melted this $\mathrm{Si}$ high phosphorus alloy with proper amount of FBR ${ }^{\circledR}$ silicon (purity $8 \mathrm{~N}$ ) to provide three samples with phosphorus concentrations of about 3000 , 1250, and $100 \mathrm{ppmw}$. These samples will be named $\mathrm{Si}-3000 \mathrm{P}, \mathrm{Si}-1250 \mathrm{P}$, and $\mathrm{Si}-100 \mathrm{P}$, respectively, in this article. After the re-melting process, the phosphorus concentration of each sample was measured by ICP-MS technique as 3100 ppma ( \pm 136$), 1227( \pm 25)$, and 97.3 $( \pm 2)$, respectively.

\section{B. Knudsen Effusion Mass Spectrometry (KEMS) Study}

Knudsen effusion mass spectrometry (KEMS) was applied to study the gaseous species evaporating from the Si-P samples. The schematic representation of the KEMS machine applied in this research together with the setup configuration is shown in Figure 1. More details about this technique can be found in References 56, 73. Here, as shown in Figure 1, the sample is heated up to the target temperature in a small enclosure with an orifice on top, called the Knudsen cell, which is assumed to provide the molecule-wall collisions dominating over molecule-molecule collisions in the gas phase. ${ }^{[49]}$ The Knudsen cell is heated up in high vacuum conditions, and the pressure condition in the Knudsen cell is low $(<10 \mathrm{~Pa})$, leading to a molecular beam effusing out of the cell's orifice. Under these conditions the gases inside the Knudsen cell can be considered as an ideal gas. By establishing thermodynamic equilibrium in the Knudsen cell, there will be equilibrium among the gases in gas phase and between the gas phase and condensed phase. Therefore, from a thermodynamic point of view, there is no difference if species are formed in the gas phase or on the melt surface. The molecular beam is redirected to an ionization chamber, where the gas molecules get ionized in a strong electric field. The ions leaving the ionization chamber pass through an electromagnetic field, where they are classified based on their mass over charge $(\mathrm{m} / \mathrm{z})$ ratio.

Previous studies ${ }^{[7]}$ indicated that the best refractory for holding liquid $\mathrm{Si}$ at high temperatures and vacuum conditions is graphite, while at the crucible/melt interface a $\mathrm{SiC}$ layer is spontaneously formed and maintained. To minimize $\mathrm{Si}$ loss via $\mathrm{SiC}$ formation, our Si-P samples (about $50-75 \mathrm{mg}$ ) were put in a tiny $\mathrm{SiC}$ crucible with a height of $10 \mathrm{~mm}$ and inner diameter of $7 \mathrm{~mm}$. This crucible was put in a graphite Knudsen cell with an orifice of $0.3 \mathrm{~mm}$ diameter on the top. The Knudsen cell was then put in a tantalum crucible with a cap on it with $1 \mathrm{~mm}$ orifice in the center. Temperature of the cell was measured with pyrometer. In this case, the measured temperature and actual temperature 


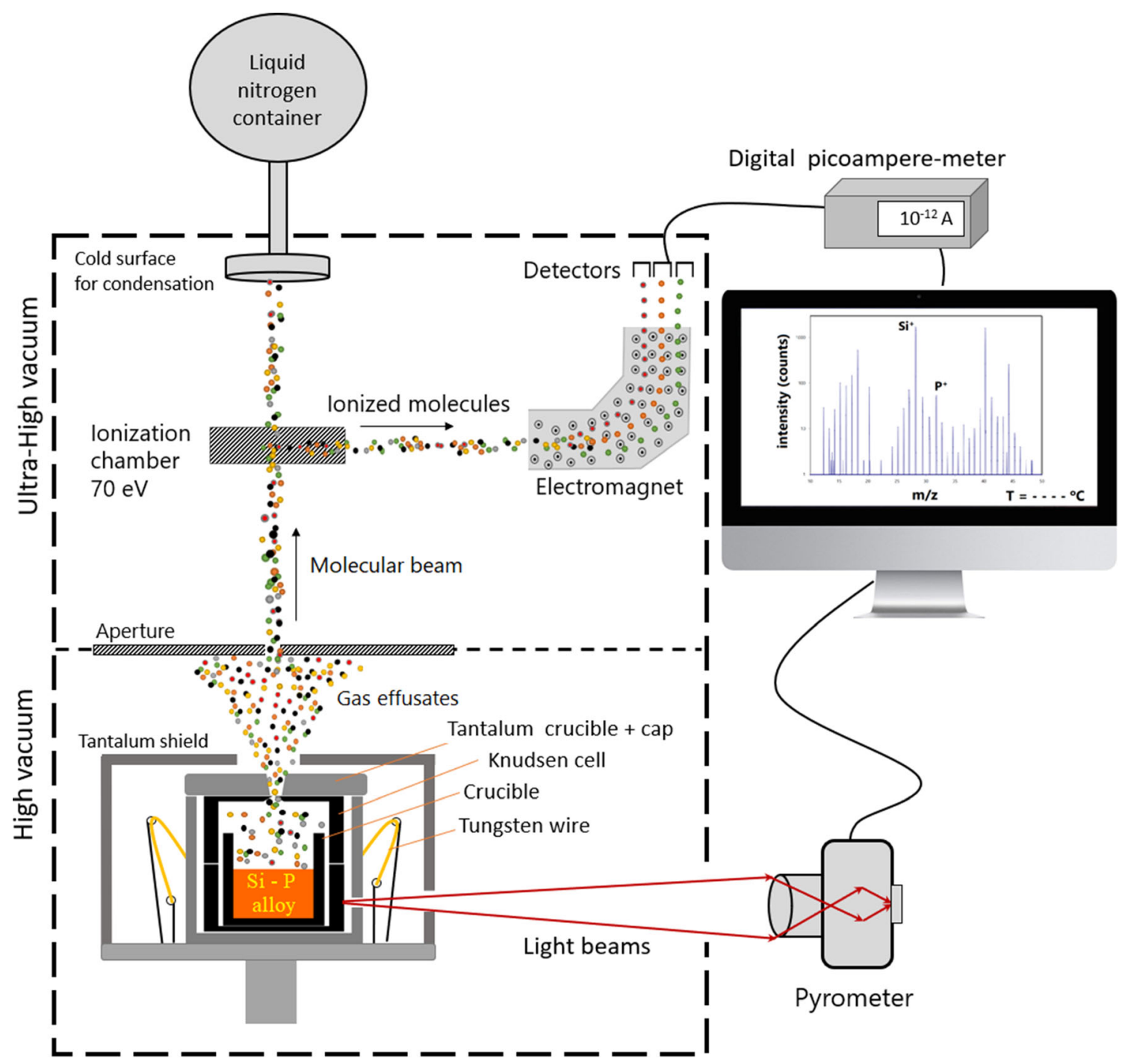

Fig. $1-$ Schematic representation of the KEMS machine applied in this study.

of the sample can deviate. Therefore, temperature and pressure calibration was performed with pure silicon ( $8 \mathrm{~N}$ purity), which is also suitable for studied samples according to the applied temperature range. The melting point of $\mathrm{Si}$ was observed in situ with ion current signal by heating the sample at $1{ }^{\circ} \mathrm{C} / \mathrm{min}$. Additional temperature calibration was also performed by using melting points of $\mathrm{Ni}$ and $\mathrm{Ag}$ (further details are available in References 52, 74). Before running the experiment, the chamber of the KEMS machine was vacuumed down to $10^{-6} \mathrm{~Pa}$, and then the power was switched on. An average heating rate of $20{ }^{\circ} \mathrm{C} / \mathrm{min}$ up to $400{ }^{\circ} \mathrm{C}$ was applied, and then the temperature was increased up to $1100{ }^{\circ} \mathrm{C}$ to $1200{ }^{\circ} \mathrm{C}$ with a fast-heating rate (around $100^{\circ} \mathrm{C} / \mathrm{min}$ ) by electron bombarding of the tantalum crucible (this is not shown in Figure 1 for simplicity). At this point, the Knudsen cell orifice was well aligned with the aperture. The sample was then heated up to about $1375^{\circ} \mathrm{C}$ at $10^{\circ} \mathrm{C} / \mathrm{min}$ and held at this temperature for a while to attain a homogeneous temperature distribution all over the cell. We did several preliminary experiments to characterize the possible gaseous species effusing out of the Knudsen cell and to check the fragmentation of the species in the ionization chamber. For this purpose, three different excitation voltages $(15,50$, and $70 \mathrm{eV})$ with the emission current of $0.15 \mathrm{~mA}$ were applied to check the fragmentation of the species effusing out of the cell. Based on these results, a constant excitation voltage of $70 \mathrm{eV}$ was used in all further experiments. Subsequently, several spectra were recorded over the range of 10 to $200 \mathrm{~m} / \mathrm{z}$, where $\mathrm{m} / \mathrm{z}$ indicates the mass over charge ratio for the ionized species. These spectra were recorded at various temperatures up to $1800{ }^{\circ} \mathrm{C}$. Based on the preliminary results, we carried out isothermal and polythermal experiments, during which the intensity of the ionized species (ions) was measured over time. In the polythermal experiments, the sample was heated up step by step, with $25{ }^{\circ} \mathrm{C}$ increase for each step. Then, the sample was held at each step for 1 hours and the intensities of the ionized species were characterized. 
After the KEMS experiments the remaining $\mathrm{Si}$ in the crucible was digested in a solution of $\mathrm{HNO}_{3}$ and $\mathrm{HF}$. Then, the liquid was characterized by ICP-MS to track the phosphorus content of the samples. Figure 2 represents the graphite Knudsen cell enclosure and the $\mathrm{SiC}$ crucible after an isothermal experiment at $1442{ }^{\circ} \mathrm{C}$ for 8 hours. The whole crucible was submerged in acid for digestion of the $\mathrm{Si}$ as shown in Figure 2(d). The sample was kept in the acid solution for 24 hours at room temperature. Then, all the $\mathrm{Si}$ in the crucible was dissolved in the acid. Figure 2(e) shows the same $\mathrm{SiC}$ crucible after digestion indicating all the $\mathrm{Si}$ was dissolved out. The weight of the $\mathrm{SiC}$ crucible after acid digestion was compared with its initial weight before the KEMS experiment (measurements carried out with Mettler Toledo ${ }^{\circledR}$, model Excellence, $0.1 \mathrm{mg}$ readability). There was no sensible weight change. After the digestion, the liquor was then characterized by ICP-MS (ICP-MS, Agilent-8800 ICP-MS Triple Quad).

\section{RESULTS}

The obtained KEMS results from the isothermal and non-isothermal experiments are presented and discussed in this section. The preliminary experiments were carried out in isothermal condition to characterize the gaseous species, and the results are presented in Section III-A. The effect of temperature is studied by polythermal experiments, presented in Section III-B.

\section{A. Isothermal KEMS Experiments}

\section{Evaporation below and above the liquidus}

Figure 3 presents two obtained mass spectra by evaporation of the $\mathrm{Si}-1250 \mathrm{P}$ sample taken of the solid sample and immediately after melting of the silicon via rapid heating to $1500{ }^{\circ} \mathrm{C} \pm 2{ }^{\circ} \mathrm{C}$. Notably, it took about 20 minutes to record each mass spectrum shown in
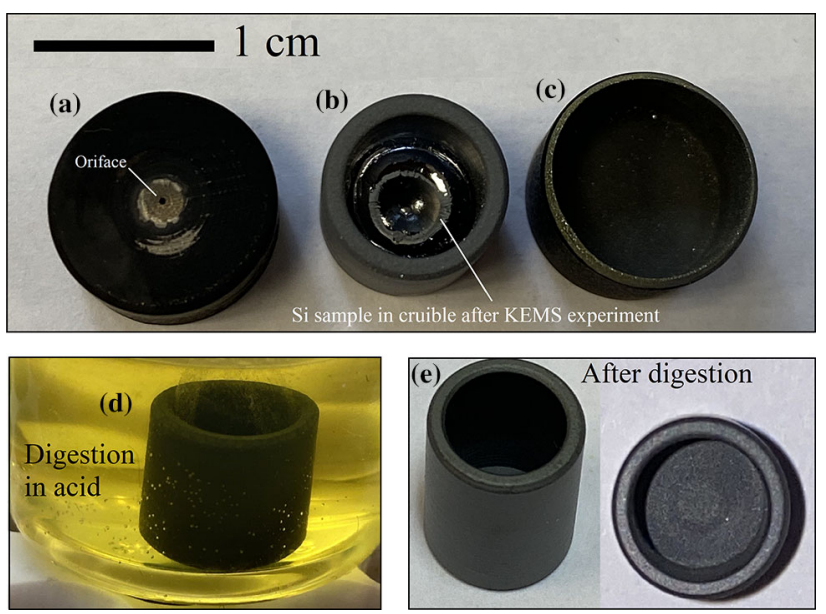

Fig. 2-Top part (lid with orifice) of the graphite Knudsen cell (a), $\mathrm{SiC}$ crucible sample holder, and Si sample after $8 \mathrm{~h}$ at $1442{ }^{\circ} \mathrm{C}(b)$, the Knudsen cell without its lid $(c)$, the $\mathrm{SiC}$ crucible submerged in acid when $\mathrm{Si}$ sample is digested $(d), \mathrm{SiC}$ crucible after complete $\mathrm{Si}$ digestion $(e)$.
Figure 3. The temperature was fixed while recording the spectra. The spectrum taken from the solid silicon at $1395{ }^{\circ} \mathrm{C}$ (Figure 3(a)) indicates that $\mathrm{Si}^{+}(\mathrm{m} / \mathrm{z} 28)$ is the dominant species. In addition, some phosphorus species can be detected in gas phase as $\mathrm{P}_{2}^{+}(\mathrm{m} / \mathrm{z} 62)$ and $\mathrm{P}^{+}(\mathrm{m} / \mathrm{z}$ 31) with high intensities and $\mathrm{SiP}^{+}\left(\mathrm{m} / \mathrm{z}\right.$ 59) and $\mathrm{Si}_{2} \mathrm{P}^{+}$ $(\mathrm{m} / \mathrm{z} 87)$ ions with low intensities. Figure 3(b) shows the intensities of $\mathrm{P}_{2}^{+}$and $\mathrm{P}^{+}$species become stronger when the sample is melted. In addition, $\mathrm{P}_{2}^{+}$is the dominant gaseous species, and the intensities of $\mathrm{P}_{2}^{+}$are five times that for $\mathrm{Si}^{+}(\mathrm{m} / \mathrm{z} 28)$. It also shows other phosphorus species such as $\mathrm{P}_{4}^{+}(\mathrm{m} / \mathrm{z} 124), \mathrm{SiP}_{2}{ }^{+}(\mathrm{m} / \mathrm{z} 90)$, and $\mathrm{Si}_{3} \mathrm{P}^{+}$ (115) with considerable intensities and $\mathrm{P}_{3}^{+}(\mathrm{m} / \mathrm{z}$ 93) are barely detectable. Obviously, we could detect phosphorus in the form of $\mathrm{SiP}^{+}, \mathrm{Si}_{2} \mathrm{P}^{+}, \mathrm{Si}_{3} \mathrm{P}^{+}$, and $\mathrm{SiP}_{2}{ }^{+}$as new results, in addition to the reported $\mathrm{P}_{2}^{+}$and $\mathrm{P}^{+}$species in the literature, over dilute solutions of phosphorus in silicon. The ion intensities of the phosphorus species detected by mass spectrometry in Figure 3 are presented in the supplementary data. It should be mentioned that the detected $\mathrm{Ar}^{+}(\mathrm{m} / \mathrm{z} 40)$ and $\mathrm{H}_{2} \mathrm{O}^{+}(\mathrm{m} / \mathrm{z}$ 18) ions come from the remaining gas in the chamber and the $\mathrm{SiO}^{+}(\mathrm{m} /$ $\mathrm{z} 44$ ) is from the reaction of remaining oxygen and $\mathrm{Si}$.

The only previous mass spectrometry study of the $\mathrm{Si}-\mathrm{P}$ system was carried out by Zaitsev et al. in Reference 63 where they studied $\mathrm{Si}-\mathrm{P}$ samples with various concentrations of phosphorus over $x_{\mathrm{P}}=0.0035-0.265$. However, they reported only the $\mathrm{P}^{\overline{+}}$ and $\mathrm{P}_{2}^{+}$species. In addition, they mentioned the intensity of $\mathrm{P}^{+}$was only 2 pct of that of $\mathrm{P}_{2}^{+}$and concluded that $\mathrm{P}^{+}$is the result of $\mathrm{P}_{2}^{+}$fragmentation in the ionization chamber $\left(\mathrm{P}_{2}+\mathrm{e}^{-}=\mathrm{P}^{+}+\mathrm{P}+2 \mathrm{e}^{-}, \Delta E=15.56 \mathrm{eV}\right)$. However, as mentioned in the experimental procedure, the studies on ion fragmentation were carried out by trying various ionization voltages $(\Delta E=15,50,70 \mathrm{eV})$, during which $\mathrm{P}^{+}$ion peak was detected with the same intensity in all the cases. This indicates that the $\mathrm{P}^{+}$ion is coming from the ionization of the $\mathrm{P}$ atoms $\left(\mathrm{P}+e^{-}=\mathrm{P}^{+}+2 e^{-}, \Delta E=10.49 \mathrm{eV}\right)$; hence, $\mathrm{P}^{+}$ions represent the monoatomic phosphorus in the molecular beam, effusing out of the Knudsen cell. The fragmentation of Si ions was studied by Tomooka et al. ${ }^{[75]}$ who showed the $\mathrm{Si}^{+}$ion comes from the monoatomic $\mathrm{Si}$ gaseous species. The discussion about fragmentations is beyond the scope of this article: further information can be found in Reference 75 .

\section{Effect of melt composition changes}

To study the phosphorus species evaporating from $\mathrm{Si}$ with time, we did a long-term isothermal experiment at $1442{ }^{\circ} \mathrm{C} \pm 2{ }^{\circ} \mathrm{C}$ on the $\mathrm{Si}-1250 \mathrm{P}$ sample as shown in Figure 4. The intensities of various species were measured in 1-hour intervals. It should be mentioned that it took about 1 hour from the melting point of Si to make the temperature steady on $1442{ }^{\circ} \mathrm{C}$. Then, the characterization was started; hence, the changes taking place over this time were not recorded. The results are presented in Figure 4(a), indicating the ion intensity of all phosphorus species decreased over the time. This is 


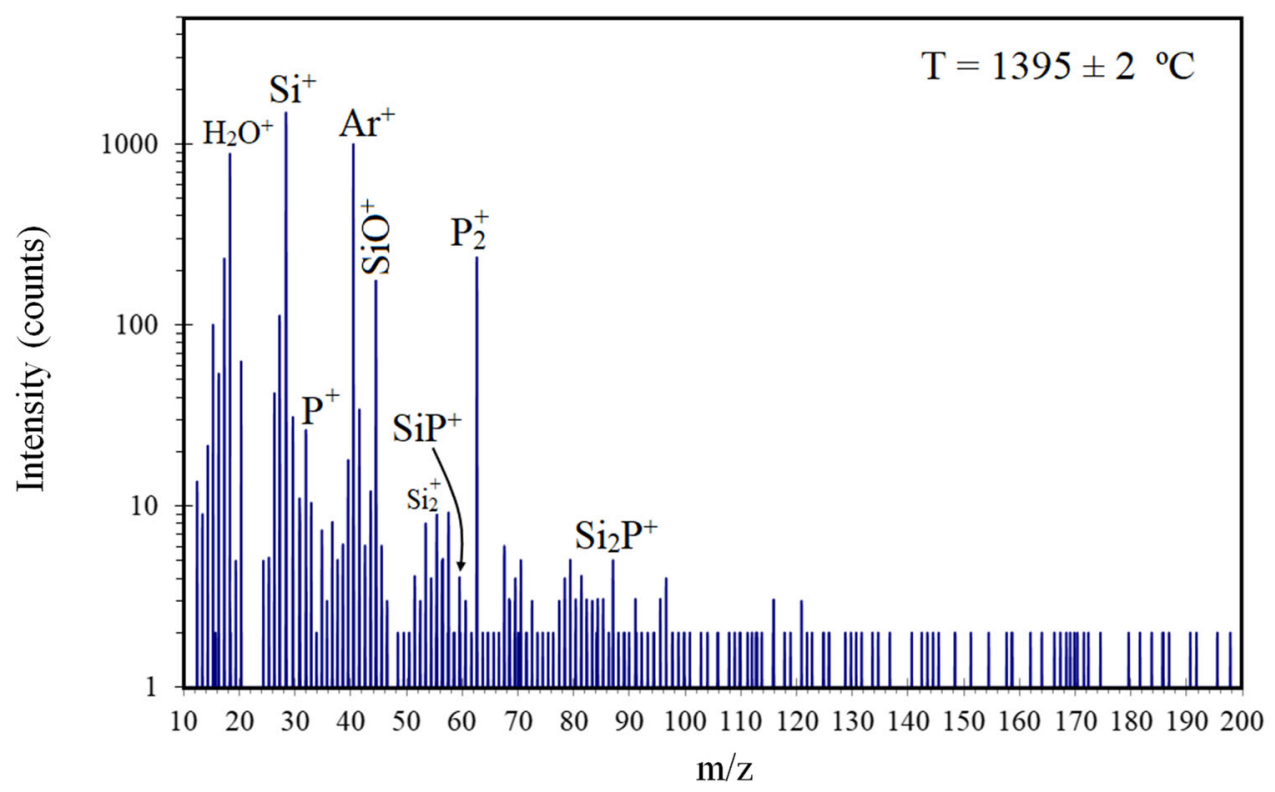

(a)

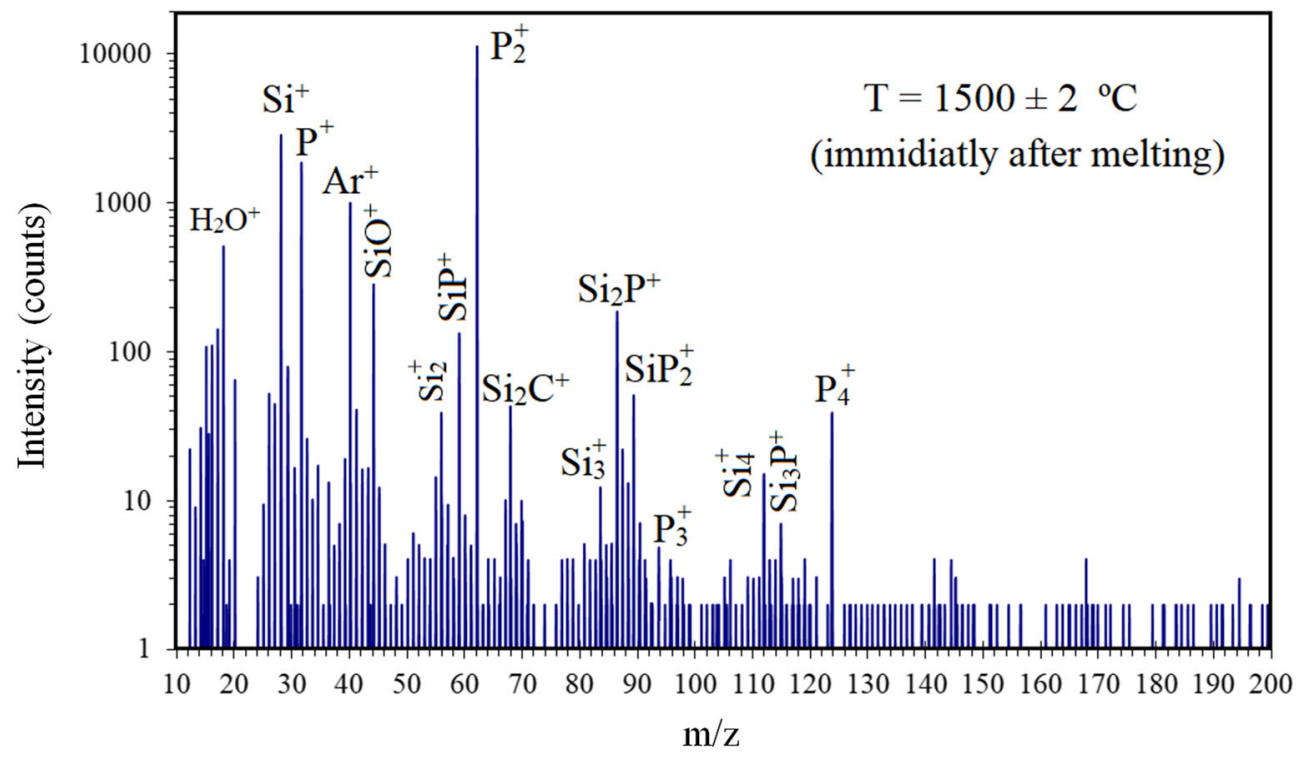

(b)

Fig. 3-KEMS raw spectra of a $\mathrm{Si}-1250 \mathrm{P}$ sample; before sample melting $(a)$ and immediately after the melting and heated up to $1500{ }^{\circ} \mathrm{C}(b)$.

due to the decrease of the phosphorus concentration in the Si melt. In the first measurement, $\mathrm{P}_{2}^{+}$and $\mathrm{P}^{+}$are the most dominant phosphorus species with close intensities in the gas phase. However, we see that $\mathrm{P}_{2}^{+}$loses its intensity faster than $\mathrm{P}^{+}$, and $\mathrm{P}^{+}$is the dominant form of phosphorus species effusing out of the Knudsen cell at longer times. The intensities of $\mathrm{Si}_{2} \mathrm{P}^{+}$and $\mathrm{SiP}^{+}$at the first measurement are significantly lower than those of $\mathrm{P}_{2}^{+}$and $\mathrm{P}^{+}$and higher than that of $\mathrm{P}_{4}^{+}$. Like all the phosphorus compounds, the intensities of $\mathrm{Si}_{2} \mathrm{P}^{+}$and $\mathrm{SiP}^{+}$decreased over time, as Figure 4 shows. Low intensities of $\mathrm{P}_{4}^{+}$were detected in the experiment compared with the above species, while $\mathrm{SiP}_{2}^{+}$was not detected in this sample, probably because of lower $\mathrm{P}^{+}$ concentration compared with the preliminary test at $1500{ }^{\circ} \mathrm{C}$. Considering the data in Figure 4, it is obvious that the intensity of $\mathrm{Si}^{+}$was constant during the time of the experiment, while the intensities of all phosphorus species decreased over the experiment time. This may indicate that the equilibrium condition (at least in short time intervals) was established for $\mathrm{Si}$ in the Knudsen cell and saturated vapor pressure was achieved, but not for 


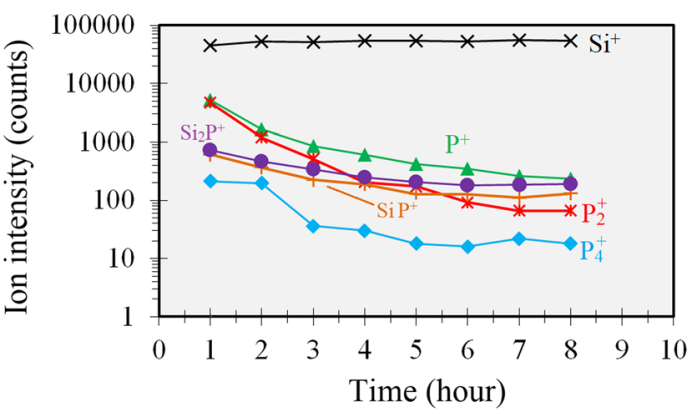

(a)

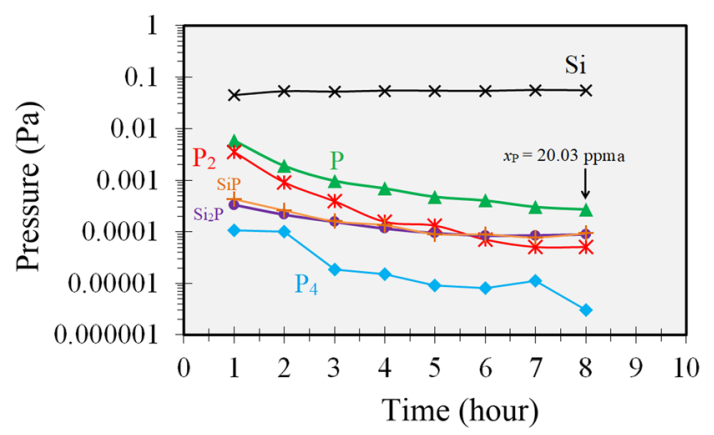

(b)

Fig. 4-Ion intensities in the isothermal experiment of $\mathrm{Si}-1250 \mathrm{P}$ sample at $1440 \pm 2{ }^{\circ} \mathrm{C}(a)$ and their corresponding calculated pressures $(b)$.

the phosphorus species. In this case, the reduction of vapor pressure is due to evaporation of phosphorus from the solution. Having the ion intensities of various compounds, we can calculate the vapor pressure of each species by applying the well-known KEMS equation presented as follows:

$$
p_{i}=\frac{k I_{i} T}{\sigma_{i}}
$$

where $p_{i}$ denotes the vapor pressure and $I_{i}$ is the intensity of the ion species $i, T$ is absolute temperature in Kelvin, $\sigma_{i}\left(\mathrm{~cm}^{2}\right)$ is ionization cross section at $70 \mathrm{eV}$, and $k$ is the sensitivity constant of the instrument. To determine the ion cross sections of the molecules, the total cross sections were calculated by the equation $\sigma_{\text {molecule }}=0.75 \sum_{i} \sigma_{\text {atom }}(i) .{ }^{[56]}$ All the used cross sections of the species are reported in Table II. To determine the instrument sensitivity coefficient $(k)$, we inserted the ion intensity of $\mathrm{Si}^{+}\left(I_{\mathrm{Si}^{+}}\right)$into Eq. [1] while the pressure of $\mathrm{Si}^{+}\left(p_{\mathrm{Si}^{+}}\right)$was taken from Reference 75 to obtain $k=2.72 \times 10^{-25}\left(\mathrm{~Pa} \mathrm{~cm}\right.$ counts $^{-1}$ $\mathrm{K}^{-1}$ ) at $1442{ }^{\circ} \mathrm{C}$.

Having all the required terms of Eq. [1], the vapor pressures of the ions at $1442{ }^{\circ} \mathrm{C}$ are calculated and depicted in Figure 4(b). This figure indicates that the vapor pressure of all phosphorus compounds reduces by experiment time since the $x_{\mathrm{P}}$ is reduced. After 8 hour of keeping the sample at $1442{ }^{\circ} \mathrm{C}$, the sample was immediately cooled down to below the Si melting point in some seconds to prevent the composition change of the liquid Si. Therefore, the phosphorus concentration in the $\mathrm{Si}$ left in the crucible will represent the $x_{\mathrm{P}}$ in liquid $\mathrm{Si}$
Table II. Ionization Cross Section of Various Species at 70

eV

\begin{tabular}{lc}
\hline Species & $\sigma, 10^{-16}\left(\mathrm{~cm}^{2}\right)$ \\
\hline $\mathrm{Si}$ & 4.905 \\
$\mathrm{P}$ & 4.2564 \\
$\mathrm{P}_{2}$ & 6.3846 \\
$\mathrm{P}_{3}$ & 9.5769 \\
$\mathrm{P}_{4}$ & 12.7692 \\
$\mathrm{SiP}$ & 6.87105 \\
$\mathrm{Si}_{2} \mathrm{P}$ & 10.5498 \\
$\mathrm{Si}_{3} \mathrm{P}$ & 14.22855 \\
$\mathrm{SiP}_{2}$ & 10.06335 \\
\hline
\end{tabular}

for the last study point shown in Figure 4(b). After the experiment, this sample was characterized by ICP-MS (as mentioned in the experimental procedure and Figure 2). The concentration of phosphorus in liquid silicon (in molar fraction, $x_{\mathrm{P}}$ ) of the last point of the experiment was determined as $x_{\mathrm{P}}=20.03$ ppma, as shown in Figure 4(b).

\section{B. Polythermal KEMS Experiments}

\section{Temperature effect}

Figure 5 shows the ion intensities of the phosphorus species evaporated at various temperatures for the Si-3000 P sample. In this sample, we had intensive evaporation due to the high content of $\mathrm{P}$ in $\mathrm{Si}$, which could damage the instruments. Therefore, we only measured five species $\left(\mathrm{Si}, \mathrm{P}, \mathrm{P}_{2}, \mathrm{P}_{4}\right.$, and $\left.\mathrm{SiP}\right)$. Figure 5 shows that $\mathrm{Si}$ exhibits a symmetrical profile over the heating and cooling cycles, which indicates the steady state was established for Si evaporation in the Knudsen cell. However, it is not the case for phosphorus-containing molecules. It is obvious from Figure 5 that the intensities of all phosphorus-containing species are reduced in both the heating and cooling cycles, which happens because of the depletion of $\mathrm{P}$ in the melt. The purpose of presenting Figure 5 was to indicate the phosphorus content is always decreasing in the $\mathrm{Si}-\mathrm{P}$ sample because of faster evaporation and loss compared to $\mathrm{Si}$; hence, it leads to the reduction of the intensities of the phosphorus-containing species. However, we will show that temperature has a bigger effect and at higher temperatures the intensities of phosphorus-containing species increase again.

2. Phosphorus concentration and temperature changes

To get a better view of the temperature effect on the evaporation of phosphorus species from $\mathrm{Si}$ melt, we characterized three samples with various phosphorus contents in liquid Si. The vapor pressures of the studied species in the polythermal experiments are calculated by applying Eq. [1], and the results are shown in Figure 6. The raw data from KEMS experiments, including the ion intensities can be found in the supplementary data of this article. Figure 6 shows that the vapor pressure of $\mathrm{Si}$ has an exponential relation with temperature for all samples, which is reliable. The vapor pressure of silicon 


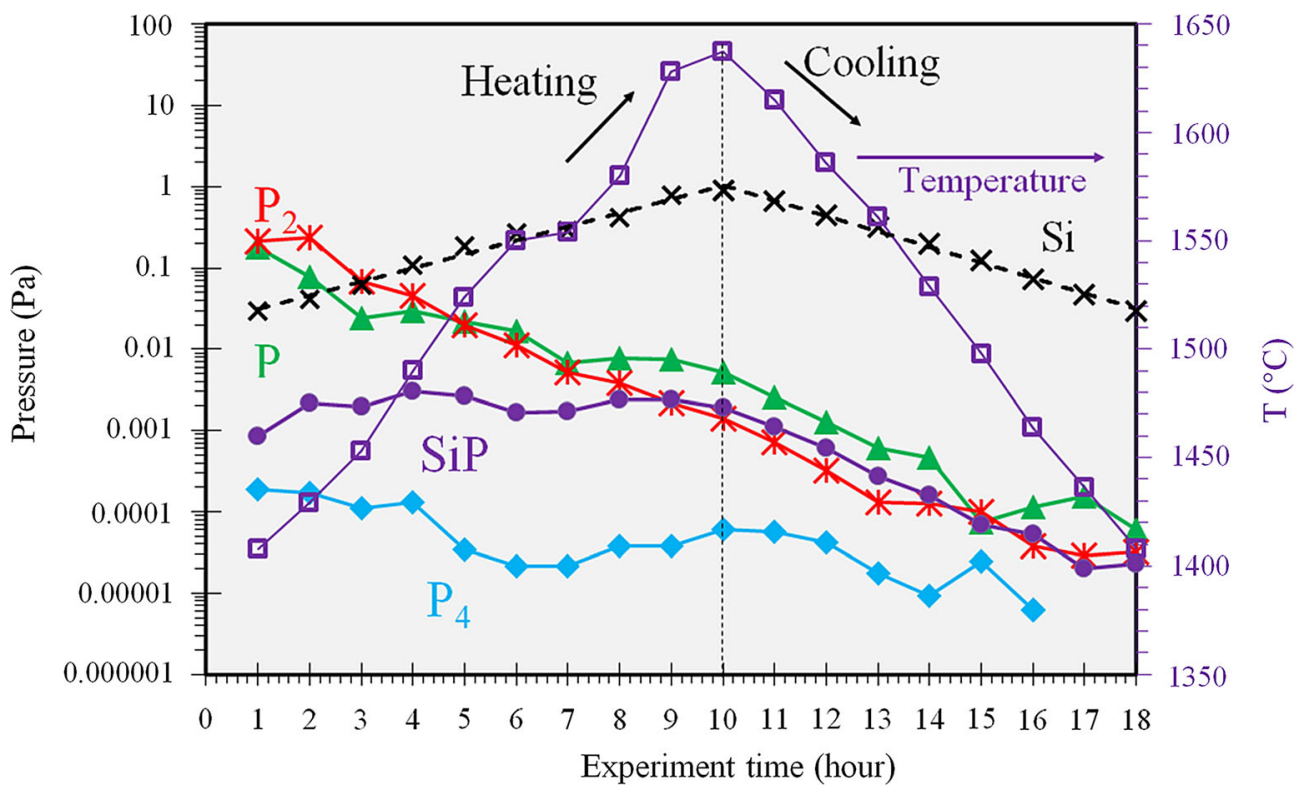

Fig. 5-Effect of temperature on the vapor pressure of various compounds in $\mathrm{Si}-3000 \mathrm{P}$ sample over heating and cooling cycle.

from the literature, ${ }^{[76]}$ which is also plotted in Figure 6, is in good agreement with our measurements. However, the vapor pressure of phosphorus species decreases by the temperature increase in both the heating and cooling cycles because of the phosphorus concentration decline in the liquid Si. Figure 6 indicates that the pressure of $\mathrm{P}_{2}$ is dominant at the beginning for all the samples (regardless of the initial $x_{\mathrm{P}}$ ), and it is declining faster compared to the other species, which agrees with the isothermal experiment (Figure 4). In addition, Figure 6 indicates that the interception point of $\mathrm{P}_{2}$ with $\mathrm{P}$ shifts toward higher temperatures when the initial phosphorus content in the samples is higher, as the interception temperatures are $1450{ }^{\circ} \mathrm{C}, 1470{ }^{\circ} \mathrm{C}$, and $1550{ }^{\circ} \mathrm{C}$ in samples $\mathrm{Si}-100 \mathrm{P}, \mathrm{Si}-1250 \mathrm{P}$, and $\mathrm{Si}-3000 \mathrm{P}$, respectively. The change in $\mathrm{P}_{4}$ intensity with increase in temperature is interesting. $\mathrm{P}_{4}$ intensity initially decreases and then increases upon heating to $1550{ }^{\circ} \mathrm{C}$ to $1600{ }^{\circ} \mathrm{C}$, following with a subsequent intensity rise at higher temperatures. However, in the $\mathrm{Si}-3000 \mathrm{P}$ sample the pressure of $\mathrm{P}_{4}$ is higher at the beginning and decreases by increasing the temperature, but then it increases when temperature exceeds $1550{ }^{\circ} \mathrm{C}$.

The obtained data in Figure 6 reveal that, for sample $\mathrm{Si}-100 \mathrm{P}$, the phosphorus evaporation for this sample takes place intensively by means of $\mathrm{SiP}, \mathrm{Si}_{2} \mathrm{P}$, and $\mathrm{Si}_{3} \mathrm{P}$, especially when the temperature exceeds $1680{ }^{\circ} \mathrm{C}$. Figure 6 shows that the evaporation of silicon phosphides comprises an important part of phosphorus evaporation from the $\mathrm{Si}-1250 \mathrm{P}$ sample. However, $\mathrm{P}$ was always the dominant species, getting higher intensities with simultaneous $\mathrm{P}_{2}$ intensity decline. Comparing samples $\mathrm{Si}-100 \mathrm{P}$ and $\mathrm{Si}-1250 \mathrm{P}$, it could be concluded that silicon phosphides are the dominant forms in the vapor when the phosphorus content in the sample is low and the temperature is higher, $>1650{ }^{\circ} \mathrm{C}$. It should be mentioned that since the intensive evaporation of phosphorus species is detrimental for the instrument, we had to limit the number of the species to be characterized and limit the temperature range in the samples with higher amounts of phosphorus. For this reason, in sample $\mathrm{Si}-3000 \mathrm{P}$, only $\mathrm{SiP}$ was recorded as a representative of the other silicon phosphides in this sample. Regarding the results presented by the isothermal experiments and this section, we can summarize the various phosphorus-containing species evaporating from $\mathrm{Si}$ and their condition as presented in Table III.

\section{DISCUSSIONS}

In this section we apply the results from the isothermal experiment to discuss the dependency of the vapor pressure of the phosphorus species to the $x_{\mathrm{P}}$ in $\mathrm{Si}$ at $1442{ }^{\circ} \mathrm{C} \pm 2{ }^{\circ} \mathrm{C}$. In addition, the results from polythermal experiments will be applied to discuss the mechanisms of phosphorus evaporation from silicon and will be compared with the obtained data from vacuum refining studies. ${ }^{[6]}$ We will discuss the liquid-vapor equilibrium of the $\mathrm{Si}-\mathrm{P}$ system in Section IV-A and then the various forms of phosphorus mass transfer from melt surface to gas phase (evaporation) in Section IV-B. At the end we present the possible mechanisms of phosphorus evaporation at the melt surface in Section IV-III.

\section{A. Liquid-Vapor Equilibrium for Si-P System}

The thermodynamic properties of vapor components in the $\mathrm{Si}-\mathrm{P}$ system at elevated temperatures are summarized in Table IV. We can apply the following relations to calculate the vapor pressure of various phosphorus species in equilibrium with liquid $\mathrm{Si}$, using the following relations: 

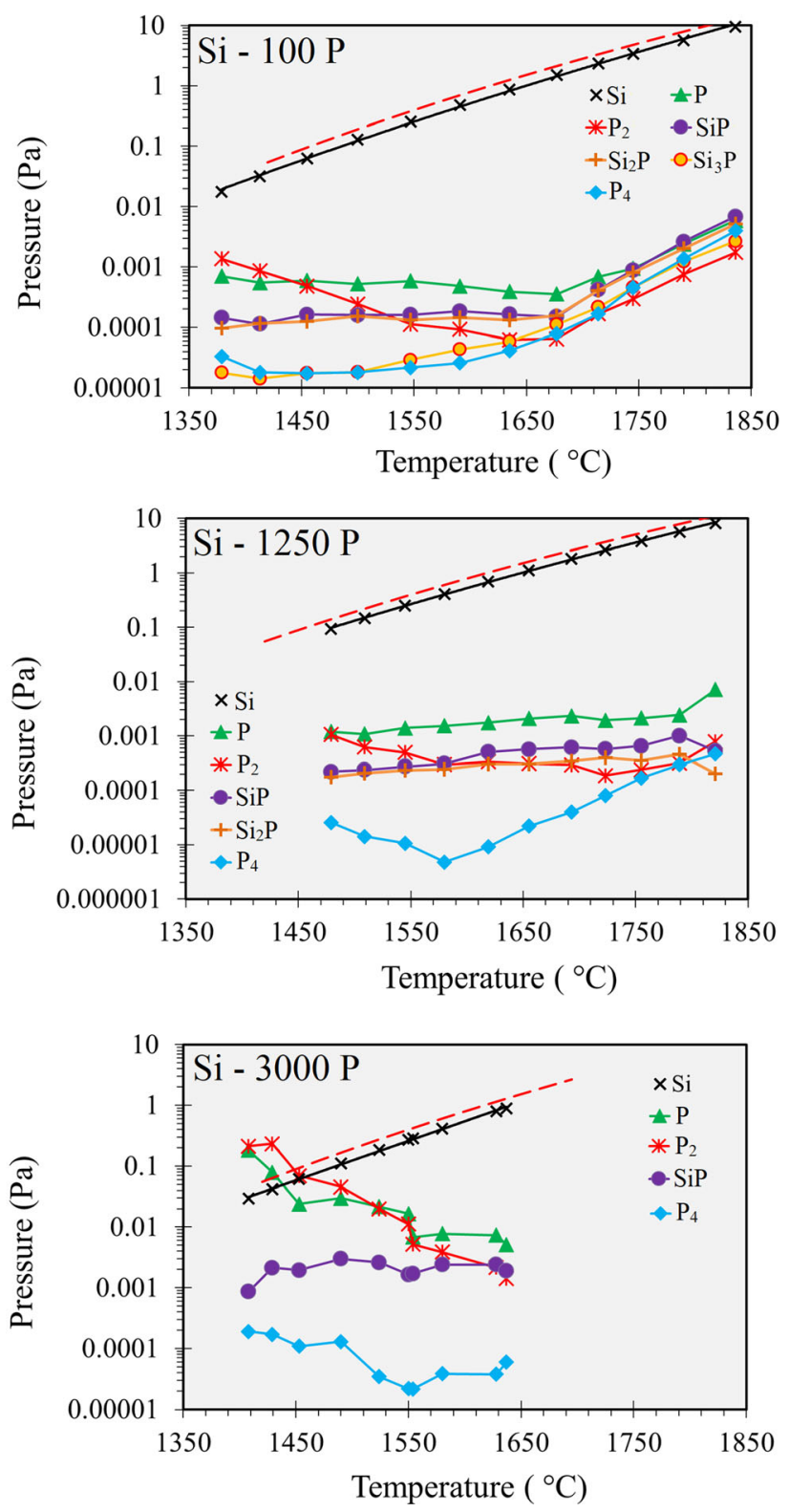

Fig. 6-Changes of the ion intensities in non-isothermal experiment of the three samples. The vapor pressure of Si from Ref. [76] is inserted for comparison (red dashed line).

$$
\begin{gathered}
p_{P}=p^{\circ} x_{\underline{P}} \gamma_{\underline{P}}^{\infty} \exp \left(-\frac{\Delta G_{\mathrm{ii}}^{\circ}+G_{\mathrm{iii}}^{\circ}}{R T}\right) \\
p_{P_{2}}=p^{\circ}\left(x_{\underline{P}} \gamma_{\underline{P}}^{\infty} \exp \left(\frac{-\Delta G_{\mathrm{iii}}^{\circ}}{R T}\right)\right)^{2} \\
p_{P_{4}}=p^{\circ}\left(x_{\underline{P}} \gamma_{\underline{P}}^{\infty} \exp \left(-\frac{\Delta G_{\mathrm{iii}}^{\circ}-0.25 \Delta G_{\mathrm{i}}^{\circ}}{R T}\right)\right)^{4}
\end{gathered}
$$

where $x_{\mathrm{P}}$ and $\gamma_{\mathrm{P}}^{\infty}$ are the phosphorus molar fraction in liquid $\overline{\mathrm{Si}}$ and the activity coefficient of phosphorus in melt, respectively, $R$ is the universal gas constant (8.314 $\mathrm{J} \mathrm{mol}^{-1} \mathrm{~K}^{-1}$ ), and $T$ is absolute temperature in Kelvin. The parameter $p^{\circ}$ is the reference pressure of the gaseous phosphorus. When applying the relation introduced by Zaitsev et al., ${ }^{[63]}$ we need to put the saturated vapor pressure of phosphorus at the studying temperature. ${ }^{[71]}$ However, when dealing with the model introduced by Miki et al. ${ }^{[62]}$ we need to assume $p^{\circ}=101325 \mathrm{~Pa}$. In addition, whenever the model of Miki et al. is applied, phosphorus weight percent in liquid silicon ( $\mathrm{P}$ wt pct) should be considered as the concentration and the weight percent interaction coefficient $\left(f_{\mathrm{P}}\right)$ should be assumed to be unity. Zaitsev et al. ${ }^{[63]}$ criticized the relationship introduced by Miki et $a .^{[62]}$ for being misprocessed and showed correct processing of the data produced by Miki et al., which are in good agreement with Zaitsev et al.'s measurements for $\mathrm{P}_{2}$. Therefore, we will apply Zaitsev et al.'s relation in this article.

Figure 7 shows the equilibrium vapor pressure of phosphorus-containing species at $1442{ }^{\circ} \mathrm{C} \pm 2{ }^{\circ} \mathrm{C}$ calculated according to Eqs. [2] through [4] and with FactSage ${ }^{\circledR}$ (version 7.3 and SGTE database). The experimental data from this research obtained by KEMS are also shown in Figure 7. Obviously, our measured vapor pressure of $\mathrm{P}_{2}$ is in good agreement with Zaitsev et al.'s measurements ${ }^{[63]}$ and calculations from FactSage ${ }^{\circledR}$. However, this is not the case for other species $\left(\mathrm{P}, \mathrm{P}_{4}, \mathrm{Si}_{2} \mathrm{P}, \mathrm{SiP}\right)$. Figure 7 indicates that FactSage ${ }^{\circledR}$ calculations underestimate the vapor pressure of $\mathrm{P}, \mathrm{SiP}$, and $\mathrm{Si}_{2} \mathrm{P}$ by about ten times of this research's measurements. However, for $\mathrm{P}_{4}$, both FactSage ${ }^{\circledR}$ and Eq. [4] underestimate the vapor pressure by about 10 billion times. Figure 7 indicates that Eqs. [2] and [4] overestimate the vapor pressure of $\mathrm{P}$ by about ten times. This could be due to the inaccuracy of the Gibbs energy for reactions ( $i$ ) and (ii); hence, Eqs. [2] and [4] cannot predict the correct vapor pressure of $\mathrm{P}$ and $\mathrm{P}_{2}$. In addition, we calculated and inserted the vapor pressure of $\mathrm{P}_{3}$ by applying the intensity of the $\mathrm{P}_{3}^{+}$ ion detected in the spectrum of the sample $\mathrm{Si}-1250 \mathrm{P}$ at $1500{ }^{\circ} \mathrm{C}$, presented in Figure 3(b). Figure 7 shows the vapor pressure of $\mathrm{P}_{3}$ calculated from FactSage ${ }^{\circledR}$ is at least 100 times lower than our measurements. We should mention that the experimental data presented in this research are unique over the concentration range and are not reported elsewhere. Therefore, the differences between the obtained experimental data and the SGTE database $^{[77]}$ could be due to extrapolation of data or modeling, which can explain the deviations observed in Figure 7 . Hence, the experimental results of this research can contribute to increasing the accuracy of the thermodynamic data for the $\mathrm{Si}-\mathrm{P}$ system.

As mentioned before, Zaitsev et al. ${ }^{[63]}$ only reported $\mathrm{P}_{2}$ ions in the $\mathrm{Si}-\mathrm{P}$ system and not any other phosphorus ions. However, we managed to measure the vapor pressure of the $\mathrm{P}, \mathrm{SiP}, \mathrm{Si}_{2} \mathrm{P}$, and $\mathrm{P}_{4}$ in addition to $\mathrm{P}_{2}$. Figure 7 shows that the vapor pressure of $P_{2}$ (for 20.03 ppma $\mathrm{P}$ in $\mathrm{Si}$ ) measured in this research is exactly on the line already introduced by Zaitsev et al. ${ }^{[63]}$ If we had the corresponding $x_{\mathrm{P}}$ of each data point shown in Figure 4, 
we could plot the vapor pressure lines for each species over the phosphorus concentration in melt. Since we showed the vapor pressure of $\mathrm{P}_{2}$ can be read by the Zaitsev et al. ${ }^{[63]}$ relation, the data for the vapor pressure of $\mathrm{P}_{2}$ can be put on the $\mathrm{P}_{2}$ line in Figure 7 , one by one, to obtain the corresponding $x_{\mathrm{P}}$ in liquid $\mathrm{Si}$ for each studied point. Having the $x_{\mathrm{P}}$ in hand, the vapor pressures of the phosphorus species already shown in Figure 4 are plotted versus the obtained $x_{\mathrm{P}}$ as presented in Figure 8. For this, the data points presented in solid fill-in Figure 8 are plotted versus the measured $x_{\mathrm{P}}$ by ICP-MS and the rest of the data are plotted versus the $x_{\mathrm{P}}$ calculated by the aforementioned method. As can be seen, there is a good correlation among the data for each species, and the obtained lines in Figure 8 have a high value of $R^{2}$, indicating the precision of the applied technique to calculate the $x_{\mathrm{P}}$ in the isothermal experiment. Figure 8 shows the dependency of the phosphorus species' vapor pressures as a function of $x_{\mathrm{P}}$ at $T=1442{ }^{\circ} \mathrm{C}$, and the vapor pressure formula for each species as a function of $x_{\mathrm{P}}$ is also presented in Table $\mathrm{V}$.

\section{B. Mass Transport of Phosphorus Via Evaporation}

Equation [1] shows that $I_{i} \cdot T$ is proportional to its pressure at any temperature. Since the pressure of species $i$ is proportional to the number of moles of $i$ $\left(p_{i}=n_{i} p_{t} / n_{t}\right)$ in the vapor, the number of moles of the species $i$ effusing out of the cell is proportional to $I_{i}$. Now, considering the various phosphorus species detected in the KEMS experiments, we can obtain a measure of the overall number of phosphorus atoms leaving the melt surface in the form of all the phosphorus-containing species presented above through the following relation:

$$
A_{t-\mathrm{P}}\left[\text { intensity } / \mathrm{cm}^{2}\right]=\sum \frac{\kappa I_{i}}{\sigma_{i}}
$$

where $A_{\mathrm{t}-\mathrm{P}}$ is a measure proportional to the total numbers of the phosphorus atoms effusing out of the Knudsen cell (removed from silicon), $I_{i}$ denotes the measured intensity of $\mathrm{P}$-containing compound $i$ ( $i$ $\left.=\mathrm{P}, \mathrm{P}_{2}, \mathrm{P}_{4}, \mathrm{SiP}, \mathrm{Si}_{2} \mathrm{P}, \mathrm{Si}_{3} \mathrm{P}, \mathrm{SiP}_{2}\right)$, and $\kappa$ is the number of the phosphorus atoms in the species $i$ (e.g., $\kappa=4$ for $\mathrm{P}_{4}$ ). Equation [5] shows that the tetratomic and diatomic phosphorus molecules have greater impact on the total number of removed phosphorus atoms. This means that, even if the amounts of diatomic and tetratomic phosphorus molecules are less than the others, they may contain more phosphorus atoms and hence could have a greater effect on the phosphorus evaporation (removal) rate. The changes of the calculated $A_{\mathrm{t}-\mathrm{P}}$ with temperature for both the $\mathrm{Si}-100 \mathrm{P}$ and $\mathrm{Si}-1250 \mathrm{P}$ samples are plotted in Figure 9(a). Obviously, the total mass of phosphorus species evaporated decreased with increasing temperature from the melting point to 1650 ${ }^{\circ} \mathrm{C}$ because of the phosphorus loss from the system. However, $A_{\mathrm{t}-\mathrm{P}}$ rises rapidly with increasing cell temperature above this temperature range. Plotting tangents over the obtained $I_{t-\mathrm{P}}$ curves, we see that $A_{t-\mathrm{P}}$ is significantly increased once the temperature exceeds
$1730{ }^{\circ} \mathrm{C}$ and $1750{ }^{\circ} \mathrm{C}$ for $\mathrm{Si}-100 \mathrm{P}$ and $\mathrm{Si}-1250$ samples, respectively. This increase in the mass transport of phosphorus in evaporation could be attributed to the intensive evaporation of silicon phosphides and $\mathrm{P}_{4}$ as observed in Figure 6. Here, it is helpful to compare these results with our previous work $^{[6]}$ on vacuum induction refining of $\mathrm{Si}$ for refining of $400 \mathrm{~g}$ of melt with $<15$ ppmw of phosphorus in liquid $\mathrm{Si}$, where we determined the mass transfer coefficient of phosphorus $\left(k_{\mathrm{P}}\right)$ at $1500{ }^{\circ} \mathrm{C}$ to $1900{ }^{\circ} \mathrm{C}$ under isothermal conditions. The results from our previous work ${ }^{[6]}$ showed that there is a large increase in the $k_{\mathrm{P}}$ at ultra-high temperatures (defined as $T>1762{ }^{\circ} \mathrm{C}=1.25 T_{\mathrm{m}, \mathrm{Si}}$ ) via a change in the mechanism of chemical evaporation reaction. The previously obtained $k_{\mathrm{P}}$ for phosphorus removal from $\mathrm{Si}$ is plotted over temperature in Figure 9(b), indicating that the $k_{\mathrm{P}}$ is changed with temperature at a significantly higher rate when the temperature exceeds about $1750{ }^{\circ} \mathrm{C}$, on average 2.6 times higher than the prediction by extrapolating $k_{P}$ from lower temperatures results. A comparison of Figure 9(a) with Figure 9(b) helps us to explain the significant $k_{\mathrm{P}}$ increase at $1750{ }^{\circ} \mathrm{C}$. In our previous works, ${ }^{[6,38]}$ we used the first-order kinetic model to explain the phosphorus concentration changes in the $\mathrm{Si}$ over time. For the application of vacuum evaporation of phosphorus for the refining of $\mathrm{Si}$, it is important to have a knowledge of the share of various phosphorus species on the removal of phosphorus. As mentioned above, some of the species contain more than one phosphorus atom; hence, they may have greater impact on phosphorus removal from silicon. To formulate the contribution of each species in the overall phosphorus removal from silicon, we introduce the following relation:

$$
\chi_{i}[p c t]=\frac{\kappa\left(I_{i} / \sigma_{i}\right)}{A_{t-P}} 100
$$

where $\chi_{i}$ denotes the impact of species $i$ ( $i=\mathrm{P}, \mathrm{P}_{2}, \mathrm{P}_{4}, \mathrm{SiP}, \mathrm{Si}_{2} \mathrm{P}, \mathrm{Si}_{3} \mathrm{P}$ ) in the total phosphorus evaporation from silicon, which is called here the evaporation impact. Figure 10 depicts $\chi_{i}$ for $\mathrm{Si}-100 \mathrm{P}$ and $\mathrm{Si}-1250 \mathrm{P}$ samples for the non-isothermal trial. In this figure, we present the sum of the phosphides $\left(\mathrm{SiP}, \mathrm{Si}_{2} \mathrm{P}, \mathrm{Si}_{3} \mathrm{P}\right)$ and hence can simply compare the share of $\mathrm{P}$ removal in the form of silicon phosphide evaporation with the molecular evaporation. Figure 10 shows that at lower temperatures $\left(T<1500{ }^{\circ} \mathrm{C}\right)$, the monoatomic and diatomic phosphorus evaporations are the dominant mechanisms for phosphorus evaporation from silicon. In addition, it is obvious that by increasing the temperature, the evaporation of silicon phosphides becomes considerable. Figure 10(a) indicates that for the $\mathrm{Si}-100 \mathrm{P}$ sample, the evaporation of silicon phosphides is the main mechanism of phosphorus removal for $T>1650{ }^{\circ} \mathrm{C}$. Beyond $1720{ }^{\circ} \mathrm{C}$, the evaporation of $\mathrm{P}_{4}$ becomes the second most effective form of phosphorus evaporation from silicon. It is obvious from Figure 10(a) that for the very dilute solution of $\mathrm{P}$ in $\mathrm{Si}$ (here $<100 \mathrm{ppm}$ ) at temperatures $>$ $1750{ }^{\circ} \mathrm{C}$, almost 71 to 76 pet of phosphorus removal is 
Table III. Detection Conditions of Various Phosphorus-Containing Ions in Mass Spectra During of Isothermal and Polythermal Experiments

\begin{tabular}{|c|c|}
\hline Ions & Detection Condition and Interpretation \\
\hline $\mathrm{P}_{2}^{+}$ & $\begin{array}{l}\text { - the dominant phosphorus species when } \mathrm{Si} \text { is solid and at the beginning of melting } \\
\text { - declines immediately after melting } \\
\text { - slightly increases at temperatures }>1650{ }^{\circ} \mathrm{C} \\
\text { - depends highly on } \mathrm{P} \text { content in } \mathrm{Si}\end{array}$ \\
\hline $\mathrm{P}^{+}$ & $\begin{array}{l}\text { - detected when } \mathrm{Si} \text { was solid as well } \\
\text { - second highest intensities at the beginning of experiments and declines with time } \\
\text { - becomes the dominant species when } \\
\text { - } \mathrm{P}_{2}^{+} \text {declines }>1450{ }^{\circ} \mathrm{C} \text { to } 1550{ }^{\circ} \mathrm{C} \text { depending on } \mathrm{P} \text { content in } \mathrm{Si} \\
\text { - it increases by temperature is stable in all temperatures and is the main phosphorus species } \\
\text { when } \mathrm{P} \text { content decreases }\end{array}$ \\
\hline $\mathrm{P}_{4}^{+}$ & $\begin{array}{l}\text { - detected only in liquid } \mathrm{Si} \\
\text { - detected at the beginning of experiments (more for higher P contents) } \\
\text { - increases intensively beyond } 1550{ }^{\circ} \mathrm{C} \text { to } 1600{ }^{\circ} \mathrm{C} \text { and higher temperatures. } \\
\text { - depends on } x_{\mathrm{P}} \text { in liquid } \mathrm{Si} \text { and evaporates intensively beyond } 1550{ }^{\circ} \mathrm{C} \text { to } 1650{ }^{\circ} \mathrm{C}\end{array}$ \\
\hline $\mathrm{P}_{3}^{+}$ & $\begin{array}{l}\text { - was barely detected only at the beginning of experiment after melting of } \mathrm{Si} \text { and in high } \\
\text { phosphorus-containing samples } \\
\text { - not a dominant phosphorus species in } \mathrm{Si}-\mathrm{P} \text { system }\end{array}$ \\
\hline $\mathrm{Si}_{3} \mathrm{P}^{+}$ & $\begin{array}{l}\text { - slightly detected at low temperature even when P content was high } \\
\text { - increases intensively with temperature even when } \mathrm{P} \text { content is low } \bullet \text { depends on temperature } \\
\text { and intensifies with silicon evaporation at higher temperatures }\end{array}$ \\
\hline $\mathrm{Si}_{2} \mathrm{P}^{+}$ & $\begin{array}{l}\text { - detected in all samples with the same intensity at low temperatures } \\
\text { - increased with temperature depends on temperature and is less dependent on P content }\end{array}$ \\
\hline $\mathrm{SiP}^{+}$ & $\begin{array}{l}\text { - detected in all samples with the same intensity at low temperatures } \\
\text { - increased with temperature depends on temperature and is less dependent on P content }\end{array}$ \\
\hline $\mathrm{SiP}_{2}^{+}$ & $\begin{array}{l}\text { - depends highly on } \mathrm{P} \text { content in } \mathrm{Si} \text { and is observed at temperatures close to liquidus } \\
\text { - only detected in } \mathrm{Si}-3000 \mathrm{P} \text { sample and disappeared rapidly after some phosphorus loss }\end{array}$ \\
\hline
\end{tabular}

Table IV. Various Phosphorus Dissolution Reactions in Silicon Melt and Their Corresponding Gibbs Energy Relations

\begin{tabular}{|c|c|c|}
\hline Relation No. & Relations and Thermodynamic Functions & References \\
\hline (i) & $\begin{array}{l}\mathrm{P}_{4(\mathrm{~g})}=2 \mathrm{P}_{2(\mathrm{~g})} \\
\Delta \mathrm{G}^{\mathrm{o}}[\mathrm{J} \mathrm{mol}\end{array}$ & Schlesinger ${ }^{[71]}$ \\
\hline (ii) & $\begin{array}{l}0.5 \mathrm{P}_{2(\mathrm{~g})}=\mathrm{P}_{(\mathrm{g})} \\
\Delta \mathrm{G}^{\circ}\left[\mathrm{J} \mathrm{mol}^{-1}\right]=248,000-59.4 T\end{array}$ & Schlesinger ${ }^{[71]}$ \\
\hline (iii) & $\begin{array}{l}\mathrm{P}=0.5 \mathrm{P}_{2(\mathrm{~g})} \\
\Delta \mathrm{G}^{\circ}\left[\mathrm{J} \mathrm{mol}^{-1}\right]=99,500-29.46 T\end{array}$ & $\begin{array}{l}\text { Zaitsev et al. }{ }^{[63]} \\
\text { (reference state for phosphorus is pure } \\
\text { phosphorus) }\end{array}$ \\
\hline (iv) & $\begin{array}{l}\mathrm{P}=0.5 \mathrm{P}_{2(\mathrm{~g})} \\
\Delta \mathrm{G}^{\circ}\left[\mathrm{J} \mathrm{mol}^{-1}\right]=139,000( \pm 2000)-43.9( \pm 10.1)- \\
T\end{array}$ & $\begin{array}{l}\text { Miki et al. }{ }^{[62]} \\
\text { (reference state for phosphorus gas is } 1 \\
\text { atm) }\end{array}$ \\
\hline $\begin{array}{l}\text { (v) } \\
\text { (vi) }\end{array}$ & $\begin{array}{l}\ln \left(\gamma_{\mathrm{P}}^{\infty}\right)=2.08-\frac{4766}{T} \\
\log \left(p_{\mathrm{P}}\right.\end{array}$ & $\begin{array}{l}\text { calculated from Zaitsev et al. }{ }^{[63]} \\
\text { Schlesinger }\end{array}$ \\
\hline
\end{tabular}

by means of $\mathrm{P}_{4}$ and silicon phosphide evaporation. However, Figure 10(b) indicates that the evaporation of silicon phosphides and $\mathrm{P}_{4}$ becomes the most considerable mechanism of phosphorus evaporation at higher temperatures. However, the monoatomic evaporation of phosphorus remains the main evaporation mechanism for $\mathrm{P}$ removal over the temperature range $1500{ }^{\circ} \mathrm{C}$ to $1820{ }^{\circ} \mathrm{C}$ because of the high content of phosphorus in this sample. The industrial metallurgical-grade silicon melts (feedstock for SoG-Si production) usually contain $<50$ ppmw phosphorus, ${ }^{[8]}$ depending on the $\mathrm{P}$ content of the utilized raw materials. Hence, the results presented in Figure 10(a) will be of great interest for the vacuum refining of silicon in practice. These results reveal that most $\mathrm{P}$ removal from silicon at ultra-high temperatures is by means of $\mathrm{P}_{4}$ 


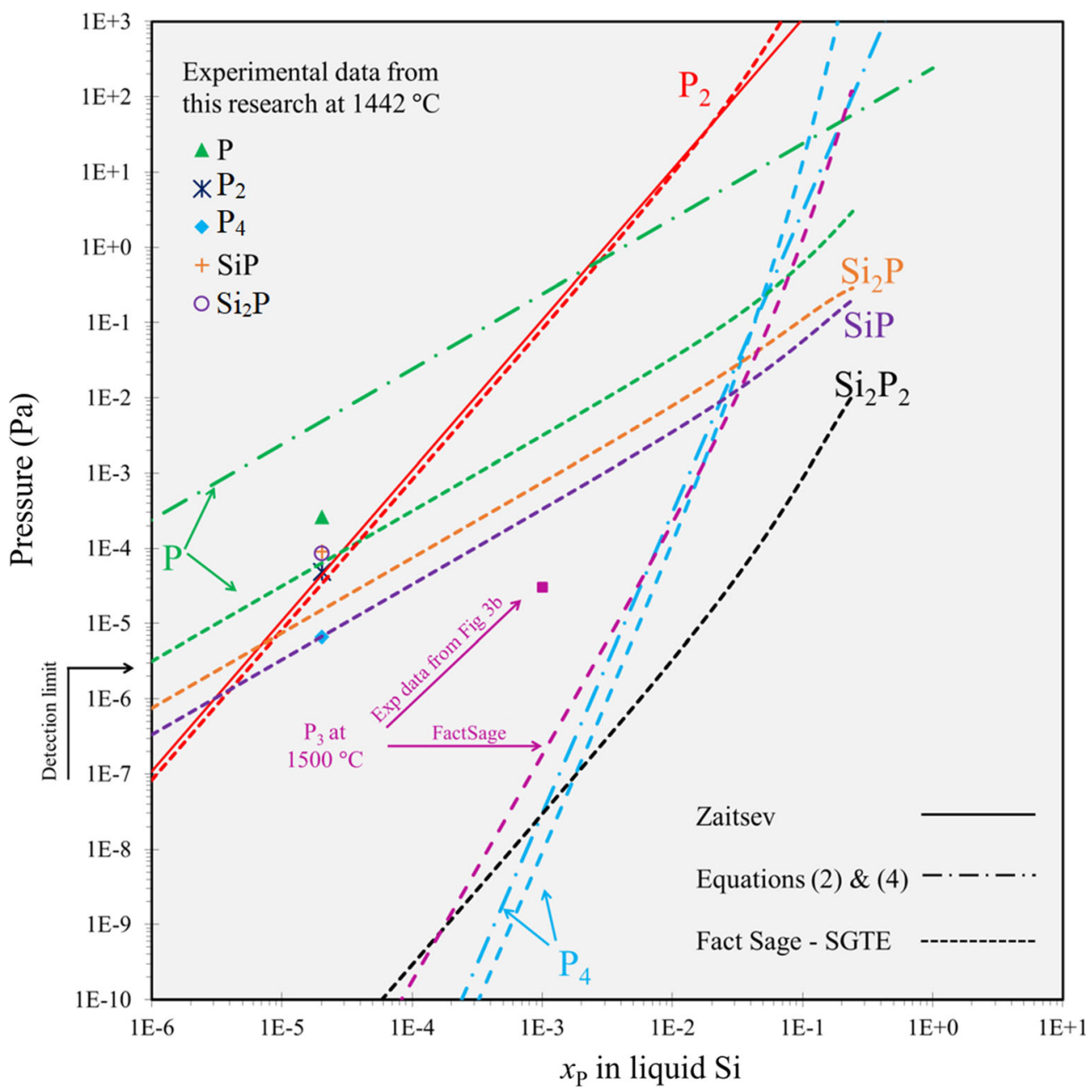

Fig. 7-Equilibrium vapor pressure of P-containing species in equilibrium with liquid $\mathrm{Si}$ at $1442{ }^{\circ} \mathrm{C}$. The curves are plotted from relations presented in the literature: Zaitsev et al., ${ }^{[63]}$ Schlesinger, ${ }^{71]}$ and using FactSage-SGTE ${ }^{[7]}$

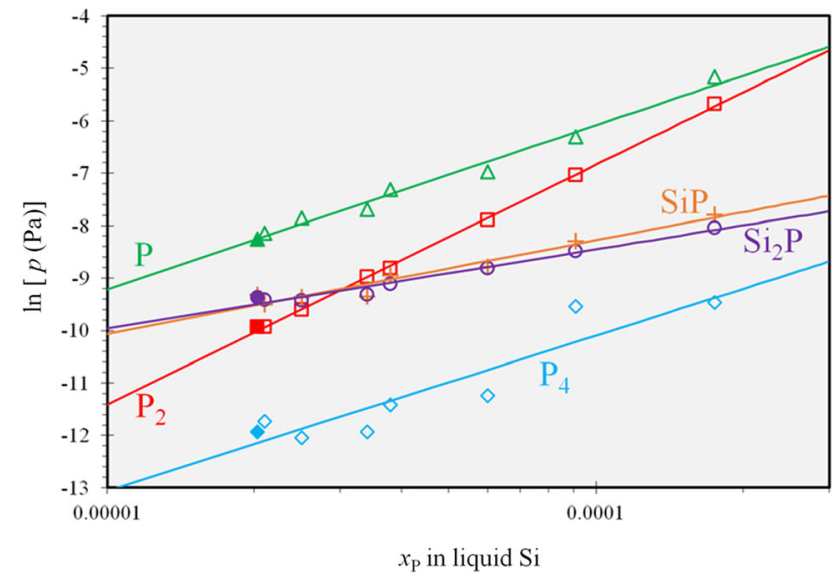

Fig. 8-Measured equilibrium vapor pressures of phosphorus-containing species over dilute $\mathrm{Si}-\mathrm{P}$ melts at $1442{ }^{\circ} \mathrm{C} \pm$ $2{ }^{\circ} \mathrm{C}$.

and silicon phosphide evaporation, while previously researchers only expected monoatomic phosphorus evaporation and in some cases diatomic phosphorus was considered for evaporation. ${ }^{[79]}$ However, we showed that phosphorus can evaporate in the form of compounds such as $\mathrm{SiP}, \mathrm{Si}_{2} \mathrm{P}, \mathrm{SiP}_{2}$, and $\mathrm{Si}_{3} \mathrm{P}$, and the contribution of these species in $\mathrm{P}$ mass transport to gas phase is higher for lower phosphorus contents and higher temperatures.

\section{Mechanisms of P Evaporation from Liquid Si}

According to the literature, phosphorus evaporates from silicon melt in the forms of $\mathrm{P}$ and $\mathrm{P}_{2}$, as we also observed, and hence the only mechanism that could be assumed was the desorption of these species from the melt surface. This mechanism, however, cannot explain our observations of silicon phosphides and the increase of $\mathrm{P}$ removal from $\mathrm{Si}-\mathrm{P}$ melt at ultra-high temperatures. We should mention that the liquid phases of the metals and alloys have short range orders, and many researchers have shown the presence of molecular clusters in the melts, such as $\mathrm{Fe}_{2} \mathrm{Al}_{5}$ and $\mathrm{Fe}_{3} \mathrm{Al}$ clusters in $\mathrm{Fe}-\mathrm{Al}$ melts, ${ }^{[80]} \mathrm{Al}_{x} \mathrm{Cu}_{y}$ clusters in $\mathrm{Al}-\mathrm{Cu}$ melts, and $\mathrm{Al}_{x} \mathrm{Ni}_{y}$ clusters in Al-Ni melts ${ }^{[81]}$. Especially when dealing with the Si melts containing $\mathrm{P}$, the high affinity of $\mathrm{Si}$ and $\mathrm{P}$ to each other should be respected. This makes $\mathrm{Si}$ and $\mathrm{P}$ 
Table V. Obtained Vapor Pressures for Various Phosphorus Species at $1442{ }^{\circ} \mathrm{C}$ as a Function of $x_{\mathrm{P}}$ in Liquid $\mathrm{Si}$

\begin{tabular}{ll}
\hline Gaseous Compound & $\ln [p(\mathrm{~Pa})]$ at $1442{ }^{\circ} \mathrm{C}$ \\
\hline $\mathrm{P}$ & $1.362 \ln \left(x_{\mathrm{P}}\right)+6.4602$ \\
$\mathrm{P}_{2}$ & $0.8686 \ln \left(x_{\mathrm{P}}\right)+5.0356$ \\
$\mathrm{P}_{4}$ & $1.2864 \ln \left(x_{\mathrm{P}}\right)+1.7528$ \\
$\mathrm{SiP}$ & $0.7735 \ln \left(x_{\mathrm{P}}\right)-1.1535$ \\
$\mathrm{Si}_{2} \mathrm{P}$ & $0.6566 \ln \left(x_{\mathrm{P}}\right)-2.4033$ \\
\hline
\end{tabular}

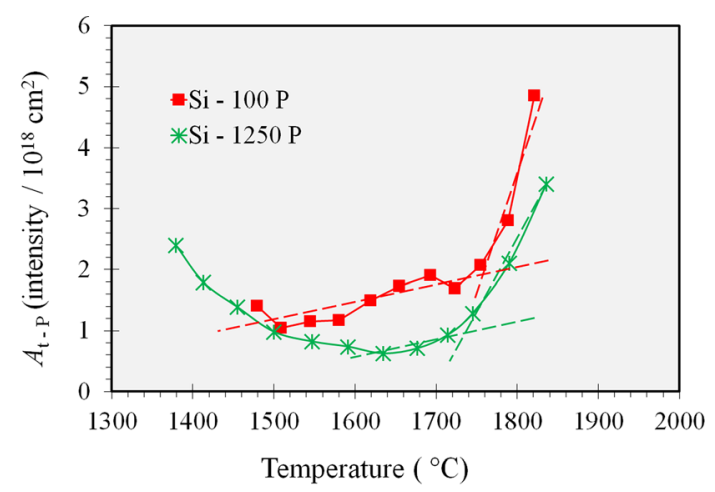

(a)

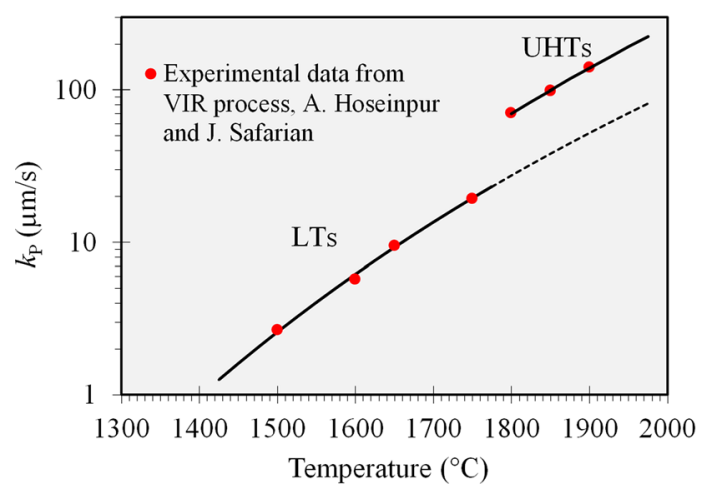

(b)

Fig. 9- Changes of $A_{t-P}$ with temperature for samples Si-100 P and $\mathrm{Si}-1250 \mathrm{P}(a)$ and the change of $k_{\mathrm{P}}$ in vacuum induction refining of silicon by temperature $(b)$; data from A. Hoseinpur and J. Safarian ${ }^{[6]}$ are included.

atoms establish strong covalent bonds and form stable compounds such as $\mathrm{SiP}, \mathrm{Si}_{2} \mathrm{P}$, and $\mathrm{SiP}_{2}$ in solid state. ${ }^{[63]}$ This strong affinity made it possible for the researchers to estimate the thermodynamic properties of the $\mathrm{Si}-\mathrm{P}$ system by the theory of associated solutions. ${ }^{[63,82,83]}$ Hence, as mentioned by Zaitsev et al., when dealing with $\mathrm{Si}-\mathrm{P}$ melts, associative groupings of $\mathrm{Si}_{x} \mathrm{P}_{y}$ are most probably possible. In other words, $\mathrm{P}$ can establish a transient bond with the adjacent $\mathrm{Si}$ atoms in the melt because of its high affinity to Si. However, it is worth noting that the formation of these groupings on the melt surface could be even more favorable than in bulk of the melt because of the lower coordination number of atoms and higher chemical activity at the surface. Once we consider the possibility of formation of this transient $\mathrm{Si}_{x} \mathrm{P}_{y}$, the decomposition of the mentioned

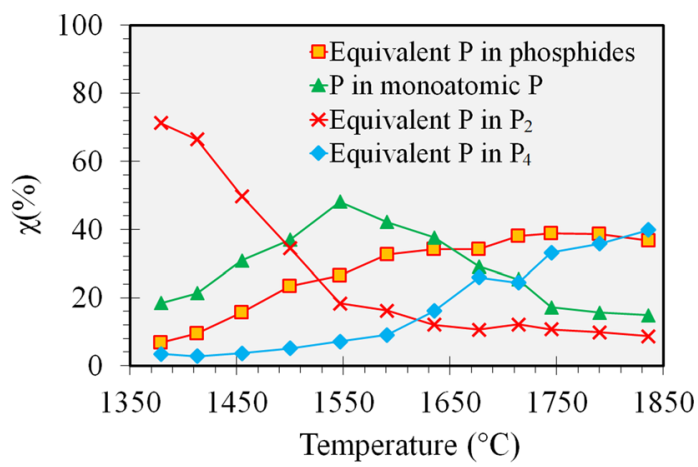

(a)

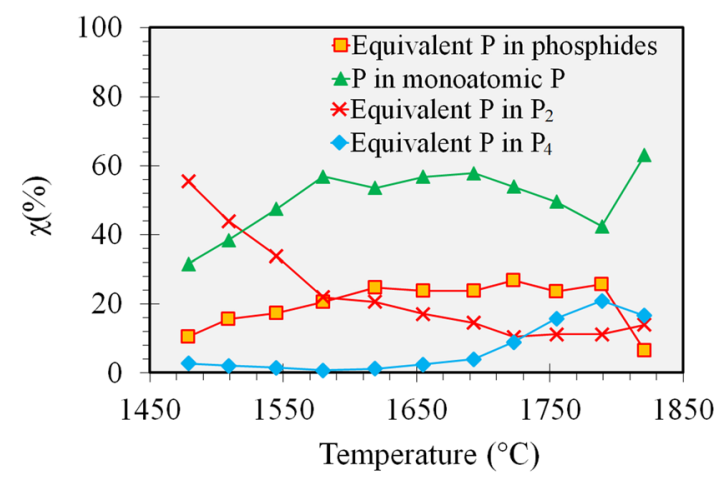

(b)

Fig. 10-Evaporation impact $\chi_{i}$ of various phosphorus-containing species in evaporation of phosphorus from silicon, (a) $\mathrm{Si}-100 \mathrm{P}$ sample and (b) $\mathrm{Si}-1250 \mathrm{P}$ sample.

$\mathrm{Si}_{x} \mathrm{P}_{y}$ groupings of atoms on the melt surface can be considered as another possible mechanism for $\mathrm{P}$ evaporation.

Using the available thermodynamic data in HSC software, ${ }^{[84]}$ the decomposition thermodynamics of the superheated $\mathrm{SiP}^{\dagger}$ and $\mathrm{SiP}_{2}^{\dagger}$ (where the superscript ${ }^{\dagger}$ indicates these are superheated compounds over the studying temperature range) up to $2000^{\circ} \mathrm{C}$ are presented in Figure 11. This figure indicates that the Gibbs energy change for reaction (e) shifts to negative values over the temperature range of $1560{ }^{\circ} \mathrm{C}$ to $1600{ }^{\circ} \mathrm{C}$, which leads to production of $\mathrm{P}_{4}$. This is in good agreement with KEMS results presented in Figure 6 where we showed the $P_{4}$ intensity increases by hitting this temperature range. In addition, the $\Delta G^{\circ}$ for reactions (a) to (d) shifts to negative values beyond $1750{ }^{\circ} \mathrm{C}$, which could explain the observed increase in $A_{\mathrm{t}-\mathrm{P}}$ in KEMS trials at high temperatures.

In polythermal KEMS experiments, we observed more formation of $\mathrm{P}_{4}$ beyond $1550{ }^{\circ} \mathrm{C}$, a significant increase in the $I_{\mathrm{t}-\mathrm{P}}$ beyond $1750{ }^{\circ} \mathrm{C}$ (Figure 9), and detection of various silicon phosphides. These can be explained by the possible decomposition of transient silicon phosphides at the melt surface. Hence, we can introduce three main groups of reactions leading to phosphorus evaporation from the melt surface, as follows:

1. Molecular evaporation: formation and desorption of phosphorus species $\left(\mathrm{P}, \mathrm{P}_{2}\right.$, and $\left.\mathrm{P}_{4}\right)$ at the melt surface. 


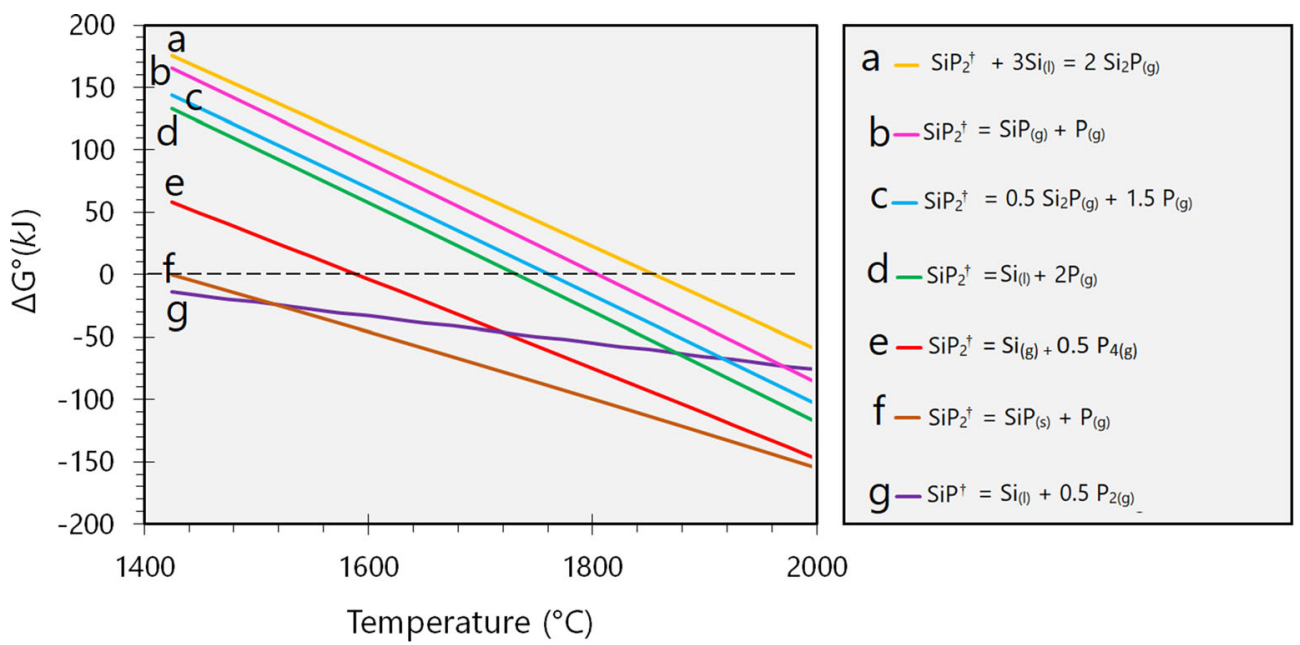

Fig. 11- Gibbs energy changes for different decomposition reactions of the superheated $\mathrm{SiP}^{\dagger}$ and $\mathrm{SiP}_{2}^{\dagger}$.

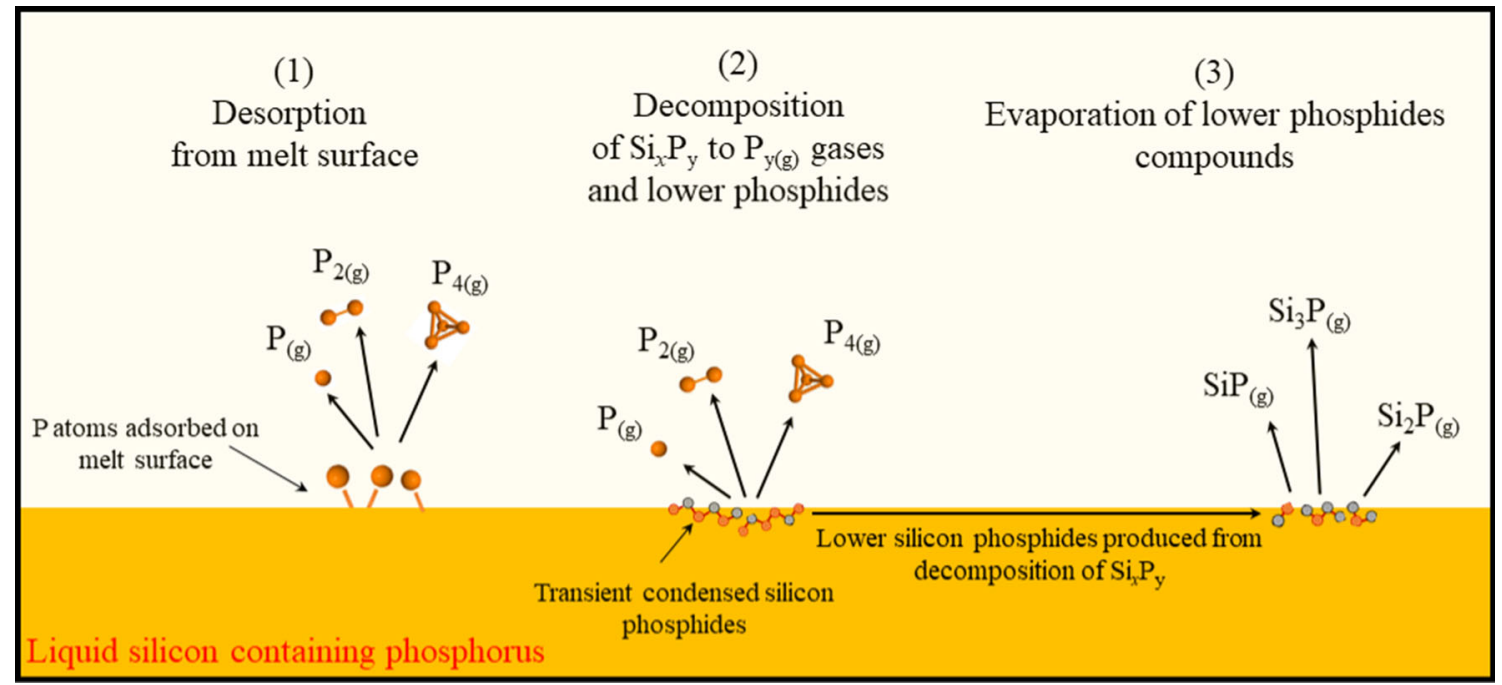

Fig. 12-Schematic representation indicating three routes for phosphorus evaporation from the silicon melt surface.

2. Decomposition of transient silicon phosphides: in this mechanism the transient silicon phosphides are decomposed to phosphorus species $\left(\mathrm{P}, \mathrm{P}_{2}\right.$, and $\left.\mathrm{P}_{4}\right)$ and other lower phosphides $\left(\mathrm{Si}_{x} \mathrm{P}_{y}\right)$.

3. Evaporation of lower silicon phosphides (formed in mechanism 2) formed at the melt surface: in this mechanism the transient silicon phosphides could directly desorb at the melt surface.

Notably, the monoatomic phosphorus desorption from the melt surface is reasonably assumable since it only requires a single atom that has already reached the melt surface to be desorbed. However, for the $\mathrm{P}_{2}$ and $\mathrm{P}_{4}$ formation and desorption, it requires two and four phosphorus atoms to join at the melt surface, respectively. Therefore, from a statistical point of view, the formation of $\mathrm{P}_{2}$ and $\mathrm{P}_{4}$ molecules and their desorption from the melt surface are less feasible as there are only a few or tens of $\mathrm{P}$ atoms per 1 million atoms of $\mathrm{Si}$ in the liquid phase. Hence, mechanism (1) via $\mathrm{P}_{2}$ and $\mathrm{P}_{4}$ formation and desorption is important at higher $\mathrm{P}$ concentrations, and for the very dilute solutions they are most likely formed via joining of $\mathrm{P}$ atoms over the surface. Obviously, in mechanism (1) we may consider that there is no significant interaction between the $\mathrm{P}$ and $\mathrm{Si}$ atoms. However, another mechanism may be the formation of a sort of bonding between the $\mathrm{P}$ and $\mathrm{Si}$ atoms at the melt surface, yielding $\operatorname{Si}_{x} \mathrm{P}_{y}$ molecules, depending on the $\mathrm{P}$ concentration. This hypothesis is logical since we observed higher intensities of $\mathrm{SiP}$ species than $\mathrm{SiP}_{2}$ by KEMS as this could be a product for the decomposition of $\mathrm{SiP}_{2}$. If $\mathrm{Si}_{x} \mathrm{P}_{y}$ molecules are formed, which is more favorable at lower $\mathrm{P}$ concentrations and higher temperatures, they will then contribute via mechanisms [2] and [3] in the $\mathrm{P}$ mass transport. Our results may suggest that at low temperatures these $\mathrm{Si}_{x} \mathrm{P}_{y}$ molecules are more decomposed to $\mathrm{P}, \mathrm{P}_{2}$, and $\mathrm{P}_{4}$ species, and with increasing temperature mechanism [3] becomes more important, particularly above $1750{ }^{\circ} \mathrm{C}$. The above 
mechanisms for phosphorus evaporation are schematically shown in Figure 12, indicating the important role of the melt surface in phosphorus evaporation from liquid $\mathrm{Si}$.

\section{CONCLUSIONS}

Vacuum evaporation of phosphorus from liquid silicon was experimentally investigated by KEMS. The following remarks should be highlighted as the outcomes of this research:

1. Various phosphorus compounds were experimentally detected by KEMS: $\mathrm{P}$ and $\mathrm{P}_{2}$ (detected before in literature) and the new $\mathrm{P}_{3}, \mathrm{P}_{4}, \mathrm{SiP}, \mathrm{Si}_{2} \mathrm{P}, \mathrm{Si}_{3} \mathrm{P}$, and $\mathrm{SiP}_{2}$ species.

2. The overall evaporation rate of phosphorus species is intensified at ultra-high temperatures, $>1650{ }^{\circ} \mathrm{C}$, which agrees well with the previous results about vacuum refining of silicon.

3. Up to about 40 pet of the evaporation could be by means of molecular silicon phosphide evaporation when initial $\mathrm{P}$ content is $<100$ ppmw and $T>1750$ ${ }^{\circ} \mathrm{C}$.

4. The evaporation of $\mathrm{P}_{4}$ molecules becomes considerable beyond $1550{ }^{\circ} \mathrm{C}$, and up to 40 pct of phosphorus removal could be by means of $\mathrm{P}_{4}$ evaporation at ultra-high temperatures $\left(T_{\mathrm{UHT}} \geq 1.25 T_{\mathrm{m}, \mathrm{Si}}\right)$.

5. The relationship between the vapor pressure of the phosphorus species $\left(\mathrm{P}, \mathrm{P}_{2}, \mathrm{P}_{4}, \mathrm{SiP}, \mathrm{Si}_{2} \mathrm{P}\right)$ and their concentrations in liquid $\mathrm{Si}$ at $1442{ }^{\circ} \mathrm{C}$ was determined.

\section{ACKNOWLEDGMENTS}

This research was financed by Norwegian University of Science and Technology (NTNU) and was done in cooperation with Jülich Research Center in Jülich, Germany. The authors thank Dr. Elena Yazhenskikh from Jülich Forschungszentrum for her comments about FactSage databases and Dr. Lars Klemet Jakobsson from Elkem in Kristiansand for his comments on the manuscript.

\section{CONFLICT OF INTEREST}

On behalf of all authors, the corresponding author states that there is no conflict of interest.

\section{FUNDING}

Open access funding provided by NTNU Norwegian University of Science and Technology (incl St. Olavs Hospital - Trondheim University Hospital).

\section{OPEN ACCESS}

This article is licensed under a Creative Commons Attribution 4.0 International License, which permits use, sharing, adaptation, distribution and reproduction in any medium or format, as long as you give appropriate credit to the original author(s) and the source, provide a link to the Creative Commons licence, and indicate if changes were made. The images or other third party material in this article are included in the article's Creative Commons licence, unless indicated otherwise in a credit line to the material. If material is not included in the article's Creative Commons licence and your intended use is not permitted by statutory regulation or exceeds the permitted use, you will need to obtain permission directly from the copyright holder. To view a copy of this licence, visit http://creat ivecommons.org/licenses/by/4.0/.

\section{SUPPLEMENTARY INFORMATION}

The online version contains supplementary material available at https://doi.org/10.1007/s11663-022-02445-1.

\section{REFERENCES}

1. E. Forniés, B. Ceccaroli, L. Méndez, A. Souto, A. Pérez Vázquez, T. Vlasenko, and J. Dieguez: Energies, 2019, vol. 12, p. 1495.

2. S. Zheng, J. Safarian, S. Seok, S. Kim, T. Merete, and X. Luo: Trans. Nonferrous Met. Soc. China, 2011, vol. 21, pp. 697-702.

3. T. Kemmotsu, T. Nagai, and M. Maeda: High Temp. Mater. Process., 2011, vol. 30, pp. 17-22.

4. S. Shi, P. Li, J. Meng, D. Jiang, Y. Tan, and H.K. Asghar: Phys. Chem. Chem. Phys., 2017, vol. 19, pp. 28424-33.

5. S.M. Karabanov, D. V. Suvorov, D.Y. Tarabrin, E. V. Slivkin, A.E. Serebryakov, V. V. Klimakov, A.S. Karabanov, and O.A. Belyakov: in 2019 IEEE International Conference on Environment and Electrical Engineering and 2019 IEEE Industrial and Commercial Power Systems Europe (EEEIC / I\&CPS Europe), IEEE, 2019, pp. $1-5$

6. A. Hoseinpur and J. Safarian: Vacuum., 2021, vol. 184, p. 109924.

7. A. Hoseinpur and J. Safarian: Vacuum, 2020, vol. 171, p. 108993.

8. M. Zhu, A. Azarov, E. Monakhov, K. Tang, and J. Safarian: Sep. Purif. Technol., 2020, vol. 240, p. 116614.

9. A. Hosseinpour and L. Tafaghodi Khajavi: Metall. Mater. Trans. B, 2019, vol. 50B, pp. 1773-81.

10. L.T. Khajavi, K. Morita, T. Yoshikawa, and M. Barati: J. Alloys Compd., 2015, vol. 619, pp. 634-38.

11. L.T. Khajavi, K. Morita, T. Yoshikawa, and M. Barati: Metall. Mater. Trans. B, 2014, vol. 46B, pp. 615-20.

12. A. Hoseinpur, S. Andersson, K. Tang, and J. Safarian: Langmuir, 2021, vol. 37, pp. 7473-85.

13. A. Hoseinpur and J. Safarian: in 35th European Photovoltaic Solar Energy Conference and Exhibition Phosphorus, Bruxel, 2018, pp. 469-72.

14. A. Hosseinpour and L. Tafaghodi Khajavi: Miner. Process. Extr. Metall. Rev., 2018, vol. 39, pp. 308-18.

15. C. Battaglia, A. Cuevas, and S. De Wolf: Energy Environ. Sci., 2016, vol. 9, pp. 1552-76.

16. Shell Scenarios: Sky - Meeting the Goals of the Paris Agreement, 2018.

17. IRENA: Future of Solar Photovoltaic: Deployment, Investment, Technology, Grid Integration and Socio-Economic Aspects, 2019.

18. A. Jäger-Waldau: PV Status Report 2019, Luxembourg, 2019.

19. S. Meyer, S. Wahl, A. Molchanov, K. Neckermann, C. Möller, K. Lauer, and C. Hagendorf: Sol. Energy Mater. Sol. Cells, 2014, vol. 130, pp. 668-72.

20. G.M. Wilson, M. Al-Jassim, W.K. Metzger, S.W. Glunz, P. Verlinden, G. Xiong, L.M. Mansfield, B.J. Stanbery, K. Zhu, Y. Yan, J.J. Berry, A.J. Ptak, F. Dimroth, B.M. Kayes, A.C. Tamboli, R. 
Peibst, K. Catchpole, M.O. Reese, C.S. Klinga, P. Denholm, M. Morjaria, M.G. Deceglie, J.M. Freeman, M.A. Mikofski, D.C. Jordan, G. TamizhMani, and D.B. Sulas-Kern: J. Phys. D, 2020, vol. 53, p. 493001.

21. L. Sun, Z. Wang, H. Chen, D. Wang, and G. Qian: Metall. Mater. Trans. B, 2017, vol. 48B, pp. 420-28.

22. Y. Li and J. Chen: Met. Mater. Int., 2020, vol. 26, pp. 526-31.

23. C. Zhang, H. Lai, Y. Zhang, Z. Sheng, J. Li, P. Xing, and X. Luo: Sep. Purif. Technol., 2020, vol. 232, p. 115954.

24. D. Jiang, S. Ren, S. Shi, W. Dong, J. Qiu, Y. Tan, and J. Li: $J$. Electron. Mater., 2014, vol. 43, pp. 314-19.

25. J. Li, H. Tang, Z. Guo, and Y. Lin: in 2013 International Conference on Materials for Renewable Energy and Environment, vol. 1, IEEE, 2013, pp. 17-20.

26. L.T. Khajavi and M. Barati: High Temp. Mater. Process., 2012, vol. 31, pp. 627-31.

27. S. Shi, P. Li, Z. Sheng, D. Jiang, Y. Tan, D. Wang, S. Wen, and H.K. Asghar: Energy, 2019, vol. 185, pp. 102-10.

28. S.M. Karabanov, D. V. Suvorov, D.Y. Tarabrin, E. V. Slivkin, A.E. Serebryakov, V. V. Klimakov, A.S. Karabanov, and O.A. Belyakov: in AIP Conference Proceedings, vol. 1999, 2018, p. 020012.

29. J.K. Lee, J.S. Lee, B.Y. Jang, J.S. Kim, Y.S. Ahn, G.H. Kang, H.E. Song, M.G. Kang, and C.H. Cho: Sol. Energy, 2015, vol. 115, pp. 322-28.

30. J. Safarian, K. Tang, and K. Hildal: in 2015 sustainable industrial processing summit, vol. 3, 2015, pp. 261-68.

31. A. Hoseinpur, G. Tranell, and J. Safarian: in silcion for the chemical and solar industry XV, 2020, pp. 261-72.

32. C. Gan, S. Wen, Y. Liu, W. Wen, J. Chen, and X. Luo: Int. J. Therm. Sci., 2021, vol. 159, p. 106615.

33. S.M. Karabanov, D.V. Suvorov, D.Y. Tarabrin, E.V. Slivkin, A.S Karabanov, O.A. Belyakov, A.A. Trubitsyn, and A. Serebryakov: MRS Adv., 2019, vol. 4, pp. 1937-47.

34. E. Forines, A. Souto, T. Velasenko, A. Perez Vazquez, M. Tojeiro, M. Anoshenko, and G. Varela: in 35th European Photovoltaic Solar Energy Conference and Exhibition PERFORMANCE, 2018, pp. 473-5.

35. L. Huang, H. Lai, C. Lu, M. Fang, W. Ma, P. Xing, X. Luo, and J. Li: J. Electron. Mater., 2016, vol. 45, pp. 541-52.

36. S. Qiu, S. Ren, L. Huang, T. Tang, M. Fang, and X. Luo: Vacuum, 2016, vol. 128, pp. 66-72.

37. D. Jiang, S. Shi, S. Ren, H. Khan Asghar, Y. Tan, P. Li, J. Qiu, and J. Li: Renew. Energy, 2015, vol. 77, pp. 463-66.

38. A. Hoseinpur, K. Tang, and J. Safarian: Sep. Purif. Technol., 2020, vol. 235 , p. 116284.

39. J. Safarian and M. Tangstad: High Temp. Mater. Process., 2012, vol. 31 , pp. 73-81.

40. J. Safarian and M. Tangstad: Metall. Mater. Trans. B, 2012, vol. 43B, pp. 1427-45.

41. J.M. Souto, Alejandro; Bullón, Javier; Ordás, Ramón; Míguez: Proc. Silicon Chem. Sol. Ind. XII, 2014, pp. 67-76.

42. I. Langmuir: J. Am. Chem. Soc., 1932, vol. 54, pp. 2798-32.

43. R.G. Remorov and M.W. Bardwell: Surf. Sci., 2005, vol. 585, pp. $59-65$.

44. K.L. Walter: Iowa State University, Digital Repository, 1972.

45. E. Bird and Z. Liang: Phys. Rev. E, 2020, vol. 102, p. 043102.

46. W. Steckelmacher: Reports Prog. Phys., 1986, vol. 49, pp. 1083-1107.

47. K. Hilpert: 1990, pp. 97-198.

48. L. Bencze, M. Rys-Matejczuk, E. Yazhenskikh, M. Ziegner, and M. Müller: Energy Fuels, 2016, vol. 30, pp. 657-65.

49. N.S. Jacobson and B.A. Kowalski: Thermodynamic Measurements Using the Knudsen Cell Technique, Ohio, 2020.

50. J. Drowart, C. Chatillon, J. Hastie, and D. Bonnell: Pure Appl. Chem., 2005, vol. 77, pp. 683-737.

51. J. Drowart: in Mass Spectrom. Proc. Int. Sch. Mass Spectrom., Ljubliana, 1971, pp. 187-242.

52. Z.H. Dong, D. Sergeev, D. Kobertz, N. D’Souza, S. Feng, M. Müller, and H.B. Dong: Metall. Mater. Trans. A, 2020, vol. 51A, pp. 309-22.
53. S. Fürtauer and H. Flandorfer: J. Alloys Compd., 2019, vol. 781, pp. $1110-18$

54. E.N. Kablov, V.L. Stolyarova, V.A. Vorozhtcov, S.I. Lopatin, and F.N. Karachevtsev: J. Alloys Compd., 2019, vol. 794, pp. 606-14.

55. O.Y. Kurapova, S.M. Shugurov, E.A. Vasileva, V.G. Konakov, and S.I. Lopatin: J. Alloys Compd., 2019, vol. 776, pp. 194-201.

56. D. Sergeev, E. Yazhenskikh, D. Kobertz, and M. Müller: Calphad Comput. Coupling Phase Diagrams Thermochem., 2019, vol. 65, pp. 42-49.

57. C.M. Arvhult, C. Guéneau, S. Gossé, and M. Selleby: J. Alloys Compd., 2018, vol. 767, pp. 883-93.

58. V.A. Vorozhtcov, V.L. Stolyarova, S.I. Lopatin, E.P. Simonenko, N.P. Simonenko, K.A. Sakharov, V.G. Sevastyanov, and N.T. Kuznetsov: J. Alloys Compd., 2018, vol. 735, pp. 2348-55.

59. Y. Wang, P. Zhou, Y. Peng, Y. Du, B. Sundman, J. Long, T. Xu, and Z. Zhang: J. Alloys Compd., 2016, vol. 687, pp. 855-66.

60. D. Henriques, V. Motalov, L. Bencze, S. Fürtauer, H. Flandorfer, and T. Markus: J. Alloys Compd., 2016, vol. 687, pp. 306-11.

61. S.-M. Liang and R. Schmid-Fetzer: J. Phase Equilibria Diffus., 2014 , vol. 35 , pp. $24-35$.

62. T. Miki, K. Morita, and N. Sano: Metall. Mater. Trans. B, 1996, vol. 27B, pp. 937-41.

63. A.I. Zaitsev, A.D. Litvina, and N.E. Shelkova: High Temp., 2001, vol. 39 , pp. 227-32.

64. S. Favre, I. Nuta, G. Chichignoud, K. Zaïdat, and C. Chatillon: ECS J. Solid State Sci. Technol., 2016, vol. 5, pp. P129-37.

65. J. Safarian, K. Tang, K. Hildal, and G. Tranell: Metall. Mater. Trans. E, 2014, vol. 1E, pp. 41-47.

66. S.S. Zheng, W.H. Chen, J. Cai, J.T. Li, C. Chen, and X.T. Luo: Metall. Mater. Trans. B, 2010, vol. 41B, pp. 1268-73.

67. S.S. Zheng, T. Abel Engh, M. Tangstad, and X.T. Luo: Sep. Purif. Technol., 2011, vol. 82, pp. 128-37.

68. T. Ikeda and M. Maeda: ISIJ Int., 1992, vol. 32, pp. 635-42.

69. S. Shi, W. Dong, X. Peng, D. Jiang, and Y. Tan: Appl. Surf. Sci., 2013, vol. 266, pp. 344-49.

70. K. Suzuki, K. Sakaguchi, T. Nakagiri, and N. Sano: J. Jpn Inst. Met., 1990, vol. 54, pp. 161-67.

71. M.E. Schlesinger: Chem. Rev., 2002, vol. 102, pp. 4267-302.

72. J. Safarian and M. Tangstad: J. Mater. Res., 2011, vol. 26, pp. 1494-503.

73. L.S. Kudin, M.F. Butman, D.N. Sergeev, V.B. Motalov, and K.W. Krämer: J. Chem. Eng. Data, 2012, vol. 57, pp. 436-38.

74. D. Spathara, D. Sergeev, D. Kobertz, M. Müller, D. Putman, and N. Warnken: J. Alloys Compd., 2021, vol. 870, p. 159295.

75. T. Tomooka, Y. Shoji, and T. Matsui: J. Mass Spectrom. Soc. Jpn., 1999, vol. 47, pp. 49-53.

76. O. Kubachewski and C.B. Alcock: Metallurgical Thermochemistry, 5th ed. Pergamon Press Ltd, New York, 1979.

77. C.W. Bale, E. Bélisle, P. Chartrand, S.A. Decterov, G. Eriksson, A.E. Gheribi, K. Hack, I.H. Jung, Y.B. Kang, J. Melançon, A.D. Pelton, S. Petersen, C. Robelin, J. Sangster, P. Spencer, and M.A. Van Ende: Calphad Comput. Coupling Phase Diagrams Thermochem., 2016, vol. 54, pp. 35-53.

78. Factsage software version 7.3, www.factsage.com.

79. S. Zheng, T.A. Engh, M. Tangstad, and X.-T. Luo: Metall. Mater. Trans. A, 2011, vol. 42A, pp. 2214-25.

80. A. Il'inskii, S. Slyusarenko, O. Slukhovskii, I. Kaban, and W. Hoyer: Mater. Sci. Eng. A, 2002, vol. 325, pp. 98-102.

81. J. Brillo, A. Bytchkov, I. Egry, L. Hennet, G. Mathiak, I. Pozdnyakova, D.L. Price, D. Thiaudiere, and D. Zanghi: J. Non. Cryst. Solids, 2006, vol. 352, pp. 4008-12.

82. A.I. Zaitsev, A.D. Litvina, N.E. Shelkova, and B.M. Mogutnov: Thermochim. Acta, 1998, vol. 314, pp. 307-15.

83. A.I. Zaitsev, Z.V. Dobrokhotova, A.D. Litvina, and B.M. Mogutnov: J. Chem. Soc. Faraday Trans., 1995, vol. 91, pp. 703-12.

84. HSC chemistry 10, http://www.hsc-chemistry.net/index.html.

Publisher's Note Springer Nature remains neutral with regard to jurisdictional claims in published maps and institutional affiliations. 